\title{
Short-Term Environmental Enrichment is a Stronger Modulator of Brain Glial Cells and Cervical Lymph Node T Cell Subtypes than Exercise or Combined Exercise and Enrichment
}

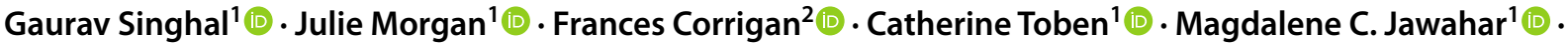

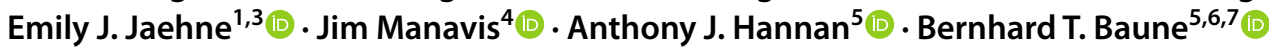

Received: 27 September 2019 / Accepted: 5 May 2020 / Published online: 25 May 2020

(c) The Author(s) 2020

\begin{abstract}
Physical exercise (PE) and environmental enrichment (EE) can modulate immunity. However, the differential effects of shortterm PE, EE, and PE + EE on neuroimmune mechanisms during normal aging has not been elucidated. Hence, a cohort of 3-, 8-, and 13-month-old immunologically unchallenged C57BL/6 wild-type mice were randomly assigned to either Control, PE, $\mathrm{EE}$, or $\mathrm{PE}+\mathrm{EE}$ groups and provided with either no treatment, a running wheel, a variety of plastic and wooden objects alone or in combination with a running wheel for seven weeks, respectively. Immunohistochemistry and 8-color flow cytometry were used to determine the numbers of dentate gyrus glial cells, and the proportions of CD4 $4^{+}$and $\mathrm{CD} 8^{+} \mathrm{T}$ cell numbers and their subsets from cervical lymph nodes, respectively. An increase in the number of IBA $1^{+}$microglia in the dentate gyrus at 5 and 10 months was observed after $\mathrm{EE}$, while PE and PE+EE increased it only at 10 months. No change in astroglia number in comparison to controls were observed in any of the treatment groups. Also, all treatments induced significant differences in the proportion of specific $\mathrm{T}$ cell subsets, i.e., $\mathrm{CD} 4^{+}$and $\mathrm{CD} 8^{+} \mathrm{T}$ naïve $\left(\mathrm{T}_{\mathrm{N}}\right)$, central memory $\left(\mathrm{T}_{\mathrm{CM}}\right)$, and effector memory $\left(\mathrm{T}_{\mathrm{EM}}\right)$ cells. Our results suggest that in the short-term, $\mathrm{EE}$ is a stronger modulator of microglial and peripheral $\mathrm{T}$ cell subset numbers than PE and PE +EE, and the combination of short-term PE and EE has no additive effects.
\end{abstract}

Keywords Environmental enrichment $\cdot$ Physical exercise $\cdot$ Aging $\cdot$ Microglia $\cdot$ Astrocytes $\cdot$ T cells

\section{Introduction}

The detrimental effects of aging on the neuroimmune system are well documented (Montecino-Rodriguez et al. 2013; Thoman and Weigle 1982). During normal aging, the immune system becomes increasingly sensitized to both intrinsic and extrinsic pathogenic factors and shows a constant functional decline, impacting health and survival. Studies have shown that microglia and astrocytes, which are essential for the innate neuroimmune and tissue repair processes and the maintenance of neurobiological homeostasis (Hanisch 2002; Rothwell et al. 1996), play a role in the onset

Electronic supplementary material The online version of this article (https://doi.org/10.1007/s10571-020-00862-x) contains supplementary material, which is available to authorized users.

Bernhard T. Baune

Bernhard.Baune@ukmuenster.de

Extended author information available on the last page of the article of inflammatory and degenerative changes in the brain during aging (Conde and Streit 2006; Schipper 1996). The glial cells of the brain become increasingly dysfunctional, lose neuroprotective properties, and secrete significantly higher levels of proinflammatory cytokines (e.g., TNF- $\alpha$, IL-1 $\beta$ ) and neurotoxic substances (e.g., reactive oxygen species, nitric oxide) during aging, which contributes to chronic neuroinflammation and subsequent neurobiological damage, cognitive dysfunction, memory deficit, and mood disorders (Mrak 2012; Patel 2013). The increased activation of hippocampal $\mathrm{IBA}^{+}$microglia and $\mathrm{GFAP}^{+}$astrocyte cells with the increased expression of IL- $1 \beta$ during aging has been reported to be responsible for neuroinflammation-associated impaired neurogenesis and loss of brain function (Kuzumaki et al. 2010).

Circulating $\mathrm{T}$ cells, which are important for cell-mediated immunity, as well as for the healthy functioning of the brain and the maintenance of neuroimmune bidirectional communication and homeostasis (Ron-Harel et al. 2011), undergo a major transformation during aging. Evidence suggests that 
there is an aging-induced reduction in the thymic output that results in a low number of naïve T cells (MontecinoRodriguez et al. 2013). As a result, while the proliferation of $\mathrm{T}$ cells continues during aging, there is a reduction in the ability to establish immunological memory in response to new antigens. Furthermore, there is a gradual decline in the number of early $\mathrm{T}$ cell activation markers and increase in the number of memory $\mathrm{T}$ cells suggestive of the adverse effects of aging on cell-mediated immunity (Moro-García et al. 2013). The significant reduction in the antigen presentation capacity of the helper $\mathrm{CD} 4^{+} \mathrm{T}$ cells and antigen elimination function of the cytotoxic $\mathrm{CD}^{+} \mathrm{T}$ cells has also been reported during normal aging (Gruver et al. 2007; Linton and Dorshkind 2004). Collectively, the alteration in peripheral $\mathrm{T}$ cell subsets during aging can predispose the brain for neuroinflammatory and neurodegenerative diseases.

The abovementioned dysregulated innate and adaptive immunity makes the aging brain prone to increased occurrence of lymphoproliferative disorders, the formation of neurotoxic amyloid-beta and tau proteins, and expression of proinflammatory cytokines and acute-phase proteins. The resultant exacerbated neuroinflammation, in turn, may act as an etiology for neurodegenerative disorders during old age, including Alzheimer's disease (AD) and dementia (Eikelenboom et al. 2006). For this reason, several pharmacological and non-pharmacological treatments have been explored in recent times to influence the aging-associated neuroimmune changes in the brain. Evidence suggests that non-pharmacological treatments, such as physical exercise (PE) and species-specific enrichment of the external environment (environmental enrichment, EE), exert a considerable influence on behavior and neuroimmune mechanisms (Baumans 2005; Singhal et al. 2014), and therefore could be utilized to modulate the neuroimmune functions associated with aging-related brain disorders. Indeed, in animal studies, these treatments (i.e., PE and EE) can be studied separately and in combination.

There are substantial evidence suggesting that hippocampus, particularly the dentate gyrus region, play a vital role in the regulation of behavior and memory in response to external stimulus (Engin and Treit 2007; Sampedro-Piquero et al. 2013; Schacter et al. 1996; Scoville and Milner 1957). Both PE and EE have been shown to enhance hippocampal neurogenesis, improve cognition, memory, and motor coordination, and alleviate mood disorders in preclinical rodent models of psychiatric disorders (Ahmadiasl et al. 2003; Binder et al. 2004; Faherty et al. 2005; Falkenberg et al. 1992; Hannan 2014; Jankowsky et al. 2005; Kempermann et al. 2002; Nichol et al. 2009; Van der Borght et al. 2007; Van Praag et al. 2005). Research has also shown that the beneficial effects of PE and EE on brain functions are the result of altered expression of peripheral T cells (Marashi et al. 2003, 2004) and brain glial cells (Chabry et al. 2015;
Ehninger and Kempermann 2003; Williamson et al. 2012). Together, this suggests that PE and EE modulate brain functions by also altering the expression of $\mathrm{T}$ cells in the periphery and glial cells in the dentate gyrus region of the hippocampus in the brain.

The paradigms of PE and EE function either at the physical or cognitive level. In PE, rodents are provided with voluntary or involuntary access to run on a wheel or treadmill, respectively, as compared with EE where mice voluntarily engage with cognitive stimuli including a range of objects of different sizes, shapes, and composition (e.g., plastic tubes, toys, ropes, ladders, tunnels, house, ramps, and platforms). It is, however, important to note that running wheels have also been used as an EE tool in a large number of studies (Berardi et al. 2007; Jankowsky et al. 2005; Kempermann et al. 2002; Leggio et al. 2005; Moncek et al. 2004; Morley-Fletcher et al. 2003; Segovia et al. 2006; Williamson et al. 2012). Since immune alterations in the brain during aging can affect behavior, mood, and cognition (Dantzer et al. 2008; Maier and Watkins 1998), this, therefore, also suggests that short-term PE, EE, and their combination could be useful as immunotherapy for age-related brain disorders.

The reported neuroimmune outcomes after short-term PE and EE, however, have been inconsistent across past studies. For instance, EE of 8 to 16 weeks has been shown to reduce the levels of cytokines IFN- $\gamma$, TNF- $\alpha$, IL-2, and IL-10 and the percentage of $\mathrm{CD}^{+}$cells in the supernatants of activated spleen cells, and improve macrophage chemotactic activity and phagocytosis, and basal lymphocyte proliferation and chemotactic activity in mice (Arranz et al. 2010; Marashi et al. 2003, 2004). Short-term PE alone has been shown to improve neuroimmune functions in rodents by enhancing NK cell activity and T suppressor cell activity (BenaroyaMilshtein et al. 2004; Kaufman et al. 1994). Furthermore, the combination of short-term PE and $\mathrm{EE}(\mathrm{PE}+\mathrm{EE})$ has been shown to increase astrocyte and microglia antigen expression in the dentate gyrus, and decrease the expression of proinflammatory cytokines TNF- $\alpha$ and IL- $1 \beta$ in the hippocampus of Sprague Dawley rats (Williamson et al. 2012). These disparate immune outcomes, therefore, create uncertainty regarding the utility of short-term PE and EE as external non-pharmacological treatments in psychiatric studies. Also, the neuroimmune outcomes may vary across the life span. For example, a preclinical study in rodents has shown that while short-term EE increases the astrocyte number and size, as well as GFAP levels, in the hippocampus and corpus callosum of young male Wistar rats, it decreases the same in old rats (Soffié et al. 1999).

The currently available literature, therefore, lacks evidence that can establish the differential neuroimmune effects of short-term PE, EE, and their combination across the lifespan. In our recently published study (Singhal et al. 2019), we found that the short-term EE of 4 weeks in the absence 
of PE improved locomotion, and reversed age-related anxiety and cognitive deficit, but showed no significant effects on depressive-like behavior. Short-term PE and PE + EE, however, were found to be ineffective. We, therefore, wanted to investigate whether the observed changes in behavior are related to underlying immune changes. Hence, all mice were sacrificed the day after behavioral testing ended for the analyses of change in numbers of astrocytes and microglia in the dentate gyrus and $\mathrm{T}$ cell subset proportions from cervical lymph nodes. C57BL/6 mice were selected for the study since they have been characterized well in terms of humoral and cellular neuroimmune responses to environmental factors (Song and Hwang 2017). The dentate gyrus region of the hippocampus was selected for molecular analysis due to its known role in the regulation of behavior and memory as mentioned previously. Since the migration of leucocytes from brain to cervical lymph nodes is established (Goldmann et al. 2006) and it has been suggested that $T$ cells from the cervical lymph nodes are good representative of the status of cellular immunity in the brain (Engelhardt et al. 2016), we selected cervical lymph nodes for the analysis of T cellmediated immunity in the brain of mice for our research.

\section{Methods}

\section{Animals}

Wild-type (C57BL/6) mice ( $n=158 ; 80$ males and 78 females), parental substrain Nhsd (derived from a colony from the National Institutes of Health, Bethesda, Maryland, USA), were bred in-house in the laboratory animal services (LAS) facility at the University of Adelaide and housed in same-sex groups of 4-5 in individually ventilated cages (IVCs) under controlled conditions of temperature $\left(21 \pm 1^{\circ} \mathrm{C}\right)$, humidity $(55 \%)$, and a $12-12$-h dark-light cycle. During experiments, the C57BL/6Nhsd line was inbred for 9-13 generations.

\section{Experimental Design}

Early age (3 m), middle age ( $8 \mathrm{~m})$, or late-middle age (13 m) mice that showed no signs of injury and sickness, hence not challenged immunologically, were randomly allocated into four groups, i.e., Control, Physical Exercise (PE), Environmental Enrichment (EE), and PE +EE, as shown in Fig. 1 and Supplementary Fig. 1. Mice were then randomly paired (males and females paired separately) and transferred to open top cages on the morning of Monday, week 1 ( 2 mice per cage unless fighting necessitated separation). Each group had 11-19 (50\% male and 50\% female) mice per age group. Control mice received no treatment and were kept in cages with the following dimensions: $48.5 \mathrm{~cm} \times 15.5 \mathrm{~cm} \times 12 \mathrm{~cm}$.
Age at which mice were housed in IVC cages and treatments (Control, EE, PE and PE+EE) started

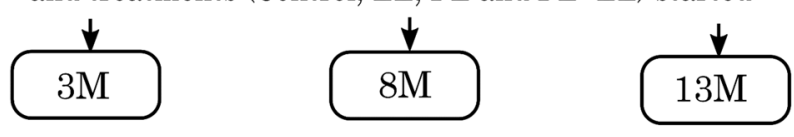

Approximate age after 4 weeks of treatment and 3 weeks and 1 day of behavioral testing

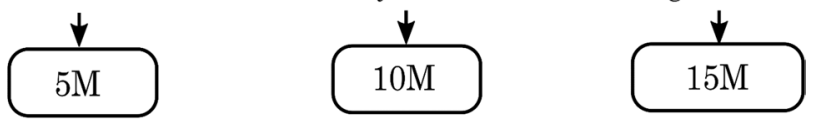

Mice were sacrificed, and brains and cervical lymph nodes were extracted for IHC and FACS analysis, respectively

Fig. 1 Schematic representation of the experimental design. $M$ months, $W$ weeks, IHC Immunohistochemistry, FACS Fluorescenceactivated cell sorting

$\mathrm{PE}, \mathrm{EE}$, and $\mathrm{PE}+\mathrm{EE}$ mice were kept in plexiglass cages with dimensions: $37 \mathrm{~cm} \times 20.5 \mathrm{~cm} \times 13.5 \mathrm{~cm}$, as these cages provided more breadth and depth to provide extra space for the objects associated with $\mathrm{EE}$ and running wheels.

The groups assigned as $\mathrm{PE}$ and $\mathrm{PE}+\mathrm{EE}$ were provided with a running wheel for 4 weeks before behavioral testing, i.e., starting at 3,8, and 13 months of age and ending at 4 , 9 , and 14 months of age, respectively. Similarly, the groups assigned as $\mathrm{EE}$ and $\mathrm{PE}+\mathrm{EE}$ were provided with a variety of non-toxic novel objects (houses, colored balls, toys, hanging toys, ladders, and tunnels) and extra bedding as per previously published protocols (Jankowsky et al. 2005; Leggio et al. 2005; Spires et al. 2004) for 4 weeks. The running wheels and EE objects remained in the cages throughout the three weeks of the behavioral testing period that followed four weeks of treatments (Fig. 1). The ages of the mice at the end of behavioral testing $(3,8$, and 13 months +7 weeks, respectively) are referred as 5, 10, and 15 months throughout the paper for the sake of simplicity.

Mice were inspected daily but handled only once a week while transferring them to clean cage every Friday morning to minimize handling stress, starting Friday of week 1. At the same time, mice were weighed on a digital weighing scale and wheel revolutions were counted using an automated counter on the wheels, the analyses of which has been published (Singhal et al. 2019). Also, the wheels were cleaned with F10SC veterinary disinfectant and the EE objects were changed to maintain novelty for mice. Mice were monitored for dominancy throughout the experiments, and those found to be highly aggressive were segregated to prevent dominance effects on neuroimmune mechanisms. Only the EE mice received nesting material (paper shreds) during the experiments. Mice underwent 3 weeks and 1 day of behavioral testing post four weeks of treatment (Fig. 1). 


\section{Molecular Analyses}

After seven weeks exposure to treatments during which all mice also underwent identical behavioral testing in the last three weeks, mice were euthanized with a lethal dose of pentobarbital $(60 \mathrm{mg} / \mathrm{kg} \mathrm{IP})$, and blood was collected through cardiac puncture (Parasuraman et al. 2010). Mice used for immunohistochemistry were perfused with $10 \%$ neutral buffered formalin via transcardiac injection, with the brains rapidly removed and preserved in $10 \%$ formalin. Mice utilized for FACS have had their draining cervical lymph nodes of the brain removed and collected in Roswell Park Memorial Institute (RPMI+) medium. It is important to note that the behavioral testing ended with the forced swim test a day before tissue collection. For full behavioral testing protocol and data analyses, see our recently published paper (Singhal et al. 2019). While both male and female mice were used to represent findings from a population comprising of both sexes in approximately equal numbers, it is important to note that we could not perform sex analysis due to low $n$ for both males and females when taken separately.

\section{Analysis of the Number of Immunopositive Glial Cell Markers (IBA1 and GFAP) in the Dentate Gyrus}

Following collection in $10 \%$ formalin, brains were cut into five $3 \mathrm{~mm}$ coronal slices and following overnight treatment with increasing concentrations and exposure of ethanol, xylene, and paraffin baths; the sliced brain samples were embedded in paraffin wax. The hippocampus was then serially sectioned, with six sections $150 \mu \mathrm{m}$ apart. Each section was $5 \mu \mathrm{m}$ thick.

For immunohistochemistry, on day 1, sections were dewaxed and dehydrated in xylene and ethanol, and endogenous peroxidase activity was blocked by incubation with $0.5 \%$ hydrogen peroxide in methanol for $30 \mathrm{~min}$. Antigen retrieval was performed by heating at close to boiling point for $10 \mathrm{~min}$ in citrate buffer, and slides were then allowed to cool below $40^{\circ} \mathrm{C}$ before further processing. The appropriate primary antibody (IBA1 for microglia, 1: 10,000; GFAP for astrocytes 1: 40,000; Abcam) was applied to the slides which were then left to incubate overnight for allowing primary antibodies to bind to the target antigen. On day 2, the IgG biotinylated antibody of rabbit (same as primary antibodies) was added and allowed to react with primary antibodies for $30 \mathrm{~min}$. The formed immune complex was then further amplified by incubating slides with a biotin-binding protein, streptavidin-peroxidase conjugate, for $60 \mathrm{~min}$. The immune complex was then visualized with precipitation of DAB in the presence of hydrogen peroxide. Slides were washed to remove excess DAB and lightly counterstained with hematoxylin, dehydrated, and mounted with DePeX.

All slides were digitally scanned using the Nanozoomer, (Hamamatsu City, Japan) and then viewed with the associated software NDP view (version 1.2.2.5). Immunopositive cells in the dentate gyrus region of the hippocampus were counted manually for statistical analysis. Freehand boxes were drawn to cover the entire dentate gyrus regions of the six stained sections followed by counting of the cells within the boxes. For each section, the total number of cells was then divided with the area of the box (in $\mathrm{mm}^{2}$ ) to get the number of cells $/ \mathrm{mm}^{2}$. The average of six sections represented the value for one mouse and was utilized during statistical analysis.

\section{Peripheral T Cell Immunophenotyping Using Fluorescence-Activated Cell Sorting (FACS)}

For the analysis of $\mathrm{T}$ cell-mediated immunity, we extracted the cervical lymph nodes and total number of T cells, $\mathrm{CD} 4^{+}$ and $\mathrm{CD} 8^{+} \mathrm{T}$ cell subpopulations (Naïve or $\mathrm{T}_{\mathrm{N}}$, Central memory or $\mathrm{T}_{\mathrm{CM}}$ and Effector memory or $\mathrm{T}_{\mathrm{EM}}$ ), and earlyactivated $\mathrm{T}$ cell phenotype $\mathrm{CD} 25$ were characterized using FACS

Cervical lymph nodes were retrieved one day after behavioral testing ended and collected in RPMI + medium. Lymph nodes were passed through a $0.1 \mu$ sieve (BD) using $\mathrm{RPMI}+$ and the end of a $1 \mathrm{~mL}$ syringe and centrifuged to separate cells from tissue debris. Retrieved lymph node cells were counted on a hemocytometer and re-suspended in PBS to a final concentration of $2 \times 10^{6}$ cells $/ \mathrm{ml}$. $250 \mu \mathrm{L}$ of the cell solution was then washed once with FACS buffer (PBS with $1 \%$ heat-inactivated bovine serum albumin) and blocked with $10 \mu \mathrm{L} 0.5 \mathrm{mg} / \mathrm{mL}$ Fc block. Eight color staining panel was used to immunophenotype $\mathrm{CD}^{+}$and $\mathrm{CD} 8^{+}$ $\mathrm{T}$ cells. Unstained cells were used to exclude autofluorescent cells, while single stained and fluorescence minus one (FMO) stained cells were used to control for spectral overlap or distinguishing between negative and positive cells, respectively (non-specific binding). Cells were incubated for $30 \mathrm{~min}$ at room temperature with the respective mAbs (as shown in Table 1) after which they were washed twice before resuspension in $300 \mu \mathrm{L}$ FACS buffer. Cells were analyzed using the Gallios flow cytometer, and 100,000 events were acquired. The data obtained were analyzed using FCS Express software (version 4). Forward side scatter gating on acquired data distinguished singlet from doublet cell populations from which $\mathrm{CD} 45^{+}$cells were gated. Percentages of $\mathrm{CD}^{+}{ }^{+} \mathrm{CD} 4^{+}$or $\mathrm{CD}^{+} \mathrm{CD}^{+}$gated cells were used to calculate total cell numbers in combination with cell counts. Further gating on $\mathrm{CD} 44^{+}$and $\mathrm{CD} 62 \mathrm{~L}^{+}$cell populations in 
Table 1 Monoclonal antibodies used for $\mathrm{T}$ cell immunophenotyping

\begin{tabular}{|c|c|c|c|c|c|}
\hline $\mathrm{mAb}$ & Clone & Fluorochromes & $\begin{array}{l}\text { BD bio- } \\
\text { sciences } \\
\text { catalog no }\end{array}$ & Conc. $(\mathrm{mg} / \mathrm{mL})$ & Antigen distribution/function \\
\hline $\mathrm{CD} 3$ & $145-2 \mathrm{C} 11$ & FITC & 553061 & $1.0 \times 10^{3}$ & $\mathrm{~T}$ cell identification marker \\
\hline $\mathrm{CD} 45$ & 30-F11 & V500 & 561487 & $2.0 \times 10^{3}$ & $\begin{array}{l}\text { Nucleated hematopoietic cell lineage marker; } \\
\text { common leukocyte antigen }\end{array}$ \\
\hline $\mathrm{CD} 4$ & GK1.5 & APC-H7 & 560181 & $2.0 \times 10^{4}$ & $\begin{array}{l}\mathrm{T} \text { helper cell co-receptor for MHC II-restricted antigen induced } \mathrm{T} \text { cell } \\
\text { activation }\end{array}$ \\
\hline $\mathrm{CD} 8$ & $53-6.7$ & PerCP-Cy5.5 & 551162 & $2.0 \times 10^{4}$ & $\begin{array}{l}\text { Cytotoxic T cell Co-receptor for MHC I restricted antigen induced T cell } \\
\text { activation }\end{array}$ \\
\hline $\mathrm{CD} 25$ & $3 \mathrm{C7}$ & PE & 561065 & $2.0 \times 10^{3}$ & Early $\mathrm{T}$ cell activation marker \\
\hline CD44 & IM7 & PerCy7 & 560569 & $5.0 \times 10^{4}$ & Activation marker for effector or memory $\mathrm{T}$ cell; attachment and rolling \\
\hline CD62L & MEL-14 & V450 & 560507 & $5.0 \times 10^{5}$ & $\mathrm{~T}$ cell homing receptor; transmigration \\
\hline CD69 & $\mathrm{H} 1.2 \mathrm{~F} 3$ & APC & 560689 & $2.0 \times 10^{3}$ & Early $\mathrm{T}$ cell activation marker \\
\hline
\end{tabular}

$m A b$ monoclonal antibody, Conc. concentration, $M H C$ major histocompatibility complex

the FCS Express software enabled identification and estimation of $\mathrm{T}$ cell subsets $\left(\mathrm{T}_{\mathrm{N}}, \mathrm{T}_{\mathrm{CM}}\right.$, and $\left.\mathrm{T}_{\mathrm{EM}}\right)$.

\section{Statistical Analysis}

Statistical analyses were conducted using GraphPad Prism version 7.02 (GraphPad Software Inc.). All data outliers were removed using the ROUT method, and normality of data distribution was determined by visual inspection of histograms. Comparisons between the treatments (PE, EE, PE + EE) and controls were performed using two-way ANOVA. The multiple comparisons post hoc Holm-Sidak's test was used to confirm significant interactions between groups. Results are presented as mean \pm SEM. Differences are considered statistically significant when $p<0.05$.

\section{Results}

\section{Alteration in Brain Microglia and Astrocyte Number in C57BL/6 Mice Exposed to PE, EE, or PE + EE at 5, 10, and 15 months of Age}

Immunopositive $\left(\mathrm{IBA} 1^{+}\right)$microglia were counted in the dentate gyrus of the hippocampus and analyzed statistically using two-way ANOVA with post hoc Holm-Sidak's multiple comparison test (Fig. 2). A significant interaction effect $\left(F_{(6,56)}=2.936 ; p<0.05\right)$ with significant main effects of treatment $\left(F_{(3,56)}=6.749 ; p<0.001\right)$ and age $\left(F_{(2,56)}=8.947 ; p<0.001\right)$ were noted. EE-treated mice showed a significantly higher number of IBA $1^{+}$microglia than control mice at both $5(90.3 \pm 2.9$ vs. $71.6 \pm 4.4$; $p<0.05)$ and 10 months $(75.4 \pm 4.2$ vs. $51.7 \pm 3.6$; $p<0.01)$ of age. Also, PE- and PE + EE-treated mice showed a significantly higher number of IBA $1^{+}$microglia than control mice at 10 months $(78.0 \pm 2.3$ and $75.8 \pm 4.2$ vs. $51.7 \pm 3.6 ; p<0.01)$. Post hoc analysis for the effect of age revealed that 10 -month controls had a significantly lower number of $\mathrm{IBA}^{+}$microglia in the dentate gyrus than both 5 -month-old $(51.7 \pm 3.6$ vs. $71.6 \pm 4.4 ; p<0.01)$ and 15 -month-old $(51.7 \pm 3.6$ vs. $78.7 \pm 7.1 ; p<0.001)$ control mice. Likewise, 15-month PE + EE-treated mice had a significantly higher number of $\mathrm{IBA} 1^{+}$microglia in the dentate gyrus than both 5-month $(95.1 \pm 8.8$ vs. $70.1 \pm 0.6 ; p<0.01)$ and 10 -month $(95.1 \pm 8.8$ vs. $75.8 \pm 2.4 ; p<0.05) \mathrm{PE}+\mathrm{EE}$ mice.

Immunopositive $\left(\mathrm{GFAP}^{+}\right)$astrocytes were counted in the dentate gyrus of the hippocampus and analyzed statistically using two-way ANOVA with post hoc Holm-Sidak's multiple comparison test (Fig. 3). Non-significant interaction effect and main effect of treatment were noted; however, the main effect of age was found to be significant $\left(F_{(2,56)}=12.73 ; p<0.0001\right)$. This was because, at 5 months of age, PE-treated mice had a significantly higher number of $\mathrm{GFAP}^{+}$astrocytes in the dentate gyrus than their cohort at 15 months of age $(311.8 \pm 13.4$ vs. $237.9 \pm 11.7 ; p<0.05)$.

\section{T Cell Immunophenotyping of Cervical Lymph Node Cells Exposed to PE, EE or PE + EE at 5, 10, and 15 Months of Age}

$\mathrm{CD}^{+}{ }^{+}$(helper $\mathrm{T}$ ) and $\mathrm{CD} 8^{+}$(cytotoxic $\mathrm{T}$ ) total cell numbers indicate the treatment-specific immune response. Representative images obtained during the FACS data analysis using FCS Express software are shown in Supplementary Figures II and III. The raw FACS data are provided in the attached supplementary excel sheet. Statistical data and group comparisons for $\mathrm{T}$ cell subsets $\left(\mathrm{T}_{\mathrm{N}}, \mathrm{T}_{\mathrm{CM}}\right.$, and $\left.\mathrm{T}_{\mathrm{EM}}\right)$ are displayed in Table 2, which are supported by Figs. 4a-e and 5a-e. 
Fig. 2 IBA $1^{+}$microglia in DG. a Representative immunohistochemical images of the number of IBA $1^{+}$microglia in the dentate gyrus of 5-, 10-, and 15 -month cohorts of animals exposed to control, $\mathrm{PE}, \mathrm{EE}$, and $\mathrm{PE}+\mathrm{EE}$ conditions (black scale represents $50 \mu \mathrm{m}$ length), and b number of $\mathrm{IBA}^{+}{ }^{+}$microglia cells where data are represented as mean \pm SEM, $n=4-8$ per group. * represents a significant difference between a treatment and age-matched control or between two treatments at one age point. " Represents a significant difference between the matched treatments over two age points. *,\# $p<0.05$, **\#\# $p<0.01,{ }^{\# \# \#} p<0.001$ a

$4 M$

9M
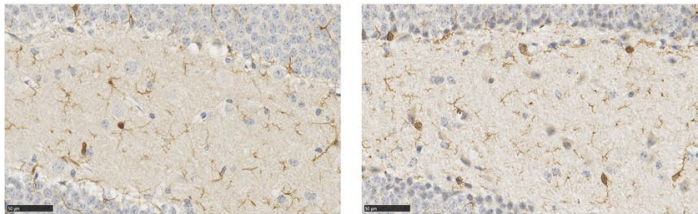

EE
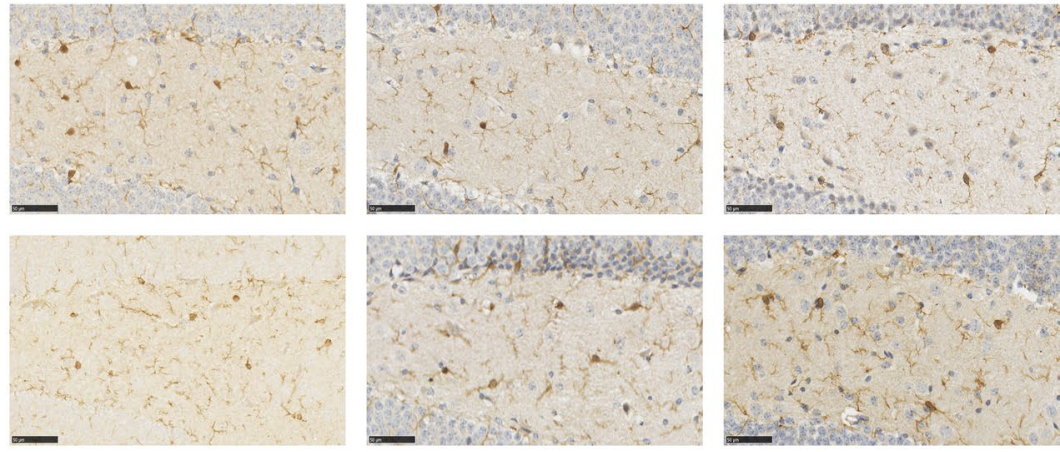

Ex

$E X+E E$
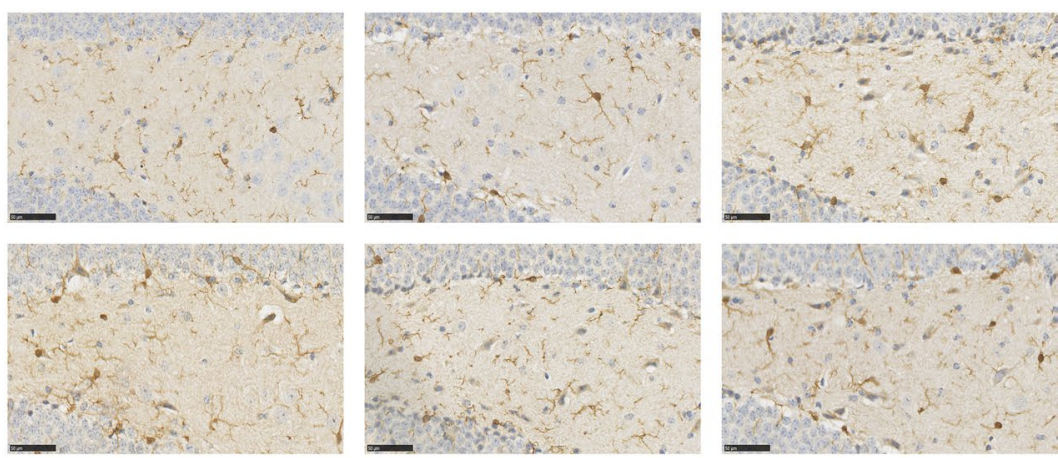

b
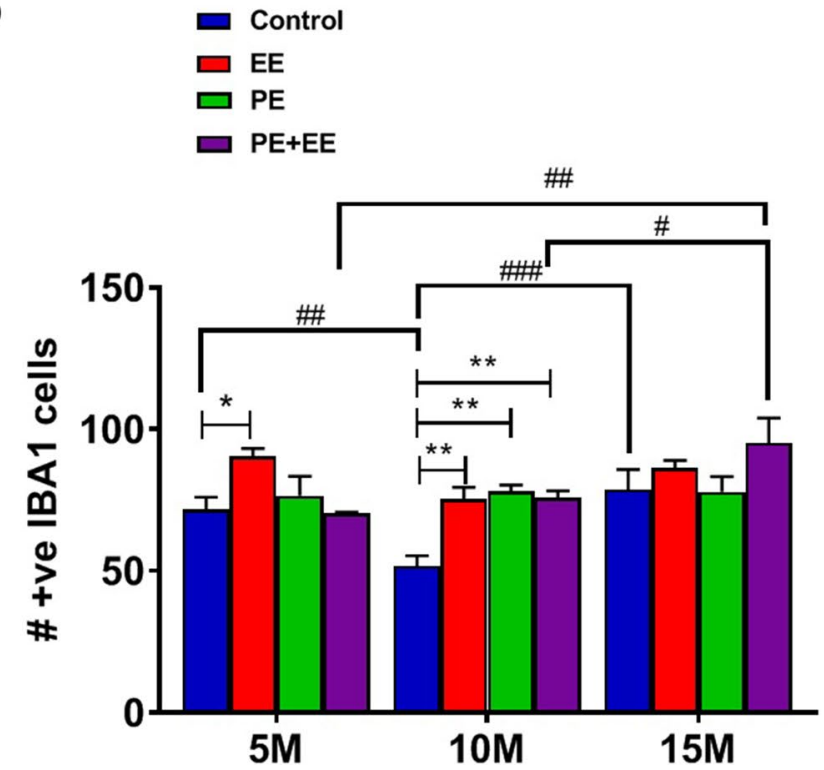

The interaction effect was non-significant for the proportion of the gated $\mathrm{CD} 4^{+} \mathrm{T}$ cells (Fig. 4a). However, the interaction effects were significant for $\mathrm{CD}^{+} \mathrm{T}_{\mathrm{CM}}$ (Table 2; Fig. 4c) and $\mathrm{T}_{\mathrm{EM}}$ (Table 2; Fig. 4d) cells. In addition, we observed significant main effects of (i) age for the $\mathrm{T}_{\mathrm{N}}$ (Table 2; Fig. 4b), $\mathrm{T}_{\mathrm{CM}}$ (Table 2; Fig. 4c), and $\mathrm{T}_{\mathrm{EM}}$ (Table 2; Fig. 4d) subsets, and (ii) treatment for the $\mathrm{T}_{\mathrm{N}}$ (Table 2; Fig. $4 \mathrm{~b}$ ) and $\mathrm{T}_{\mathrm{EM}}$ (Table 2; Fig. 4d) subsets of $\mathrm{CD}^{+}$cells.

Post hoc analysis revealed significantly higher expression of $\mathrm{CD}^{+}{ }^{+} \mathrm{T}_{\mathrm{N}}$ cells in 5-month $\mathrm{PE}+\mathrm{EE}$ mice compared to 5-month control mice, and 10-month and 15-month PE +EE mice (Table 2; Fig. 4b). Similarly, the proportion of CD4 ${ }^{+}$ $\mathrm{T}_{\mathrm{CM}}$ cells was significantly higher in 5-month $\mathrm{EE}$ and $\mathrm{PE}$ mice compared to 5-month control mice, 5-month $\mathrm{PE}+\mathrm{EE}$ mice, and respective EE and PE mice at 10 and 15 months (Table 2; Fig. 4c). The results were, however, different for $\mathrm{CD}^{+}{ }^{+} \mathrm{T}_{\mathrm{EM}}$ cells (Table 2; Fig. 4d). The 5-month control and $\mathrm{PE}+\mathrm{EE}$ mice expressed significantly higher $\mathrm{CD} 4^{+} \mathrm{T}_{\mathrm{EM}}$ cells in the cervical lymph nodes than similar-aged $\mathrm{EE}$ and $\mathrm{PE}$ mice. Furthermore, the expression of $\mathrm{CD} 4^{+} \mathrm{T}_{\mathrm{EM}}$ cells in the 
Fig. $3 \mathrm{GFAP}^{+}$astrocytes in DG. a Representative immunohistochemical images of the number of $\mathrm{GFAP}^{+}$astrocytes in the dentate gyrus of 5-, 10-, and 15 -month cohorts of animals exposed to control, $\mathrm{PE}, \mathrm{EE}$, and $\mathrm{PE}+\mathrm{EE}$ conditions (black scale represents $50 \mu \mathrm{m}$ length), and b number of $\mathrm{GFAP}^{+}$astrocyte cells where data are represented as mean \pm SEM, $n=4-8$ per group. " Represents a significant difference between the matched treatments over two age points. ${ }^{\#} p<0.05$
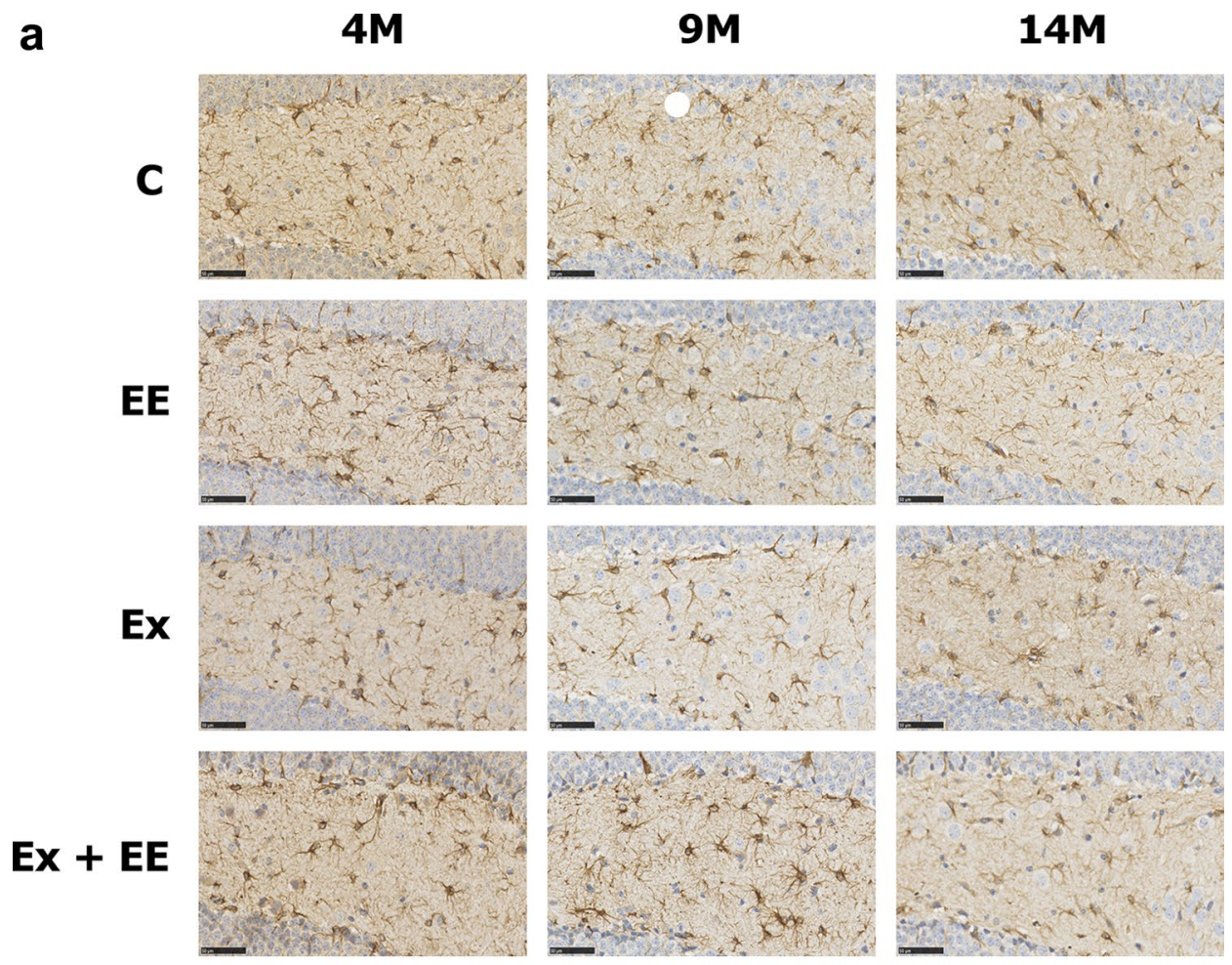

b

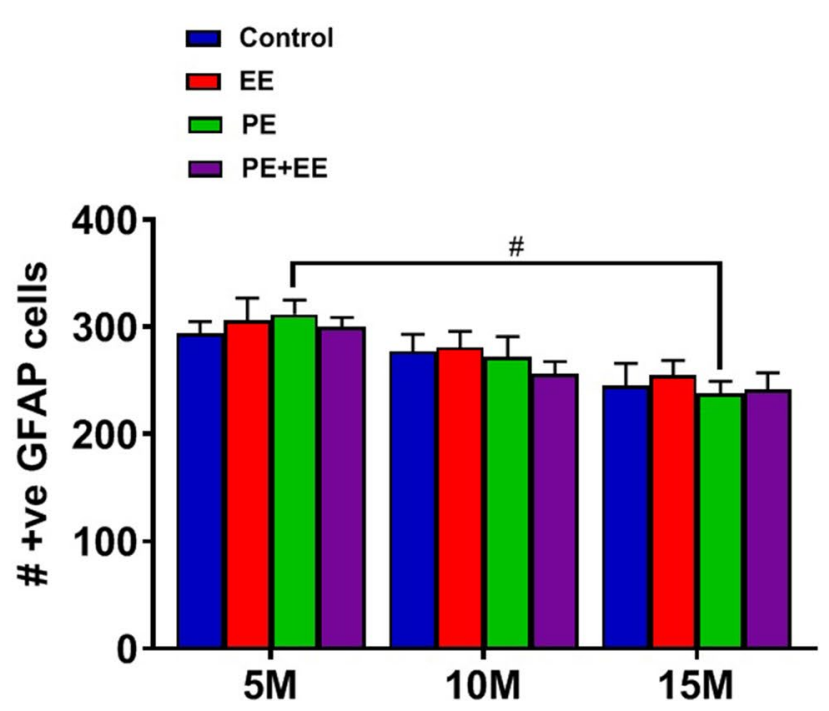

EE group at 5 months was significantly lower than EE group at 15 months. Likewise, the PE group at 5 months showed significantly lower expression of $\mathrm{CD}^{+}{ }^{+} \mathrm{T}_{\mathrm{EM}}$ cells than $\mathrm{PE}$ groups at both 10 and 15 months.

We observed a significant interaction effect for $\mathrm{CD}_{4}{ }^{+}$ $\mathrm{CD}^{2} 5^{+} \mathrm{T}$ cells (Table 2; Fig. 4e). On post hoc analysis, the 5-month PE group showed a significantly higher proportion of $\mathrm{CD}^{+} \mathrm{CD}^{+} 5^{+} \mathrm{T}_{\mathrm{EM}}$ cells than 10- and 15-month PE groups. Additionally, we observed that 5-month-old PE mice had significantly more $\mathrm{CD} 4{ }^{+} \mathrm{CD} 25^{+}$cells when compared to the same age controls.
Two-way ANOVA found significant interaction effect, as well as significant main effects of age and treatments for the proportion of $\mathrm{CD}^{+} \mathrm{T}$ cells (Table 2; Fig. 5a), with a proportion of $\mathrm{CD}^{+} \mathrm{T}$ cells significantly higher in (i) 4-month $\mathrm{PE}+\mathrm{EE}$ group compared to the same age EE and PE groups, (ii) 14-month EE group compared to the 14-month controls group, and (iii) 14-month EE group compared to the 4- and 9-month EE groups. Furthermore, we observed the significant interaction effect for $\mathrm{CD}^{+} \mathrm{T}_{\mathrm{EM}}$ cells (Table 2; Fig. 5d), significant main effects of age for $\mathrm{CD}^{+} \mathrm{TC}_{\mathrm{M}}$ (Table 2; 


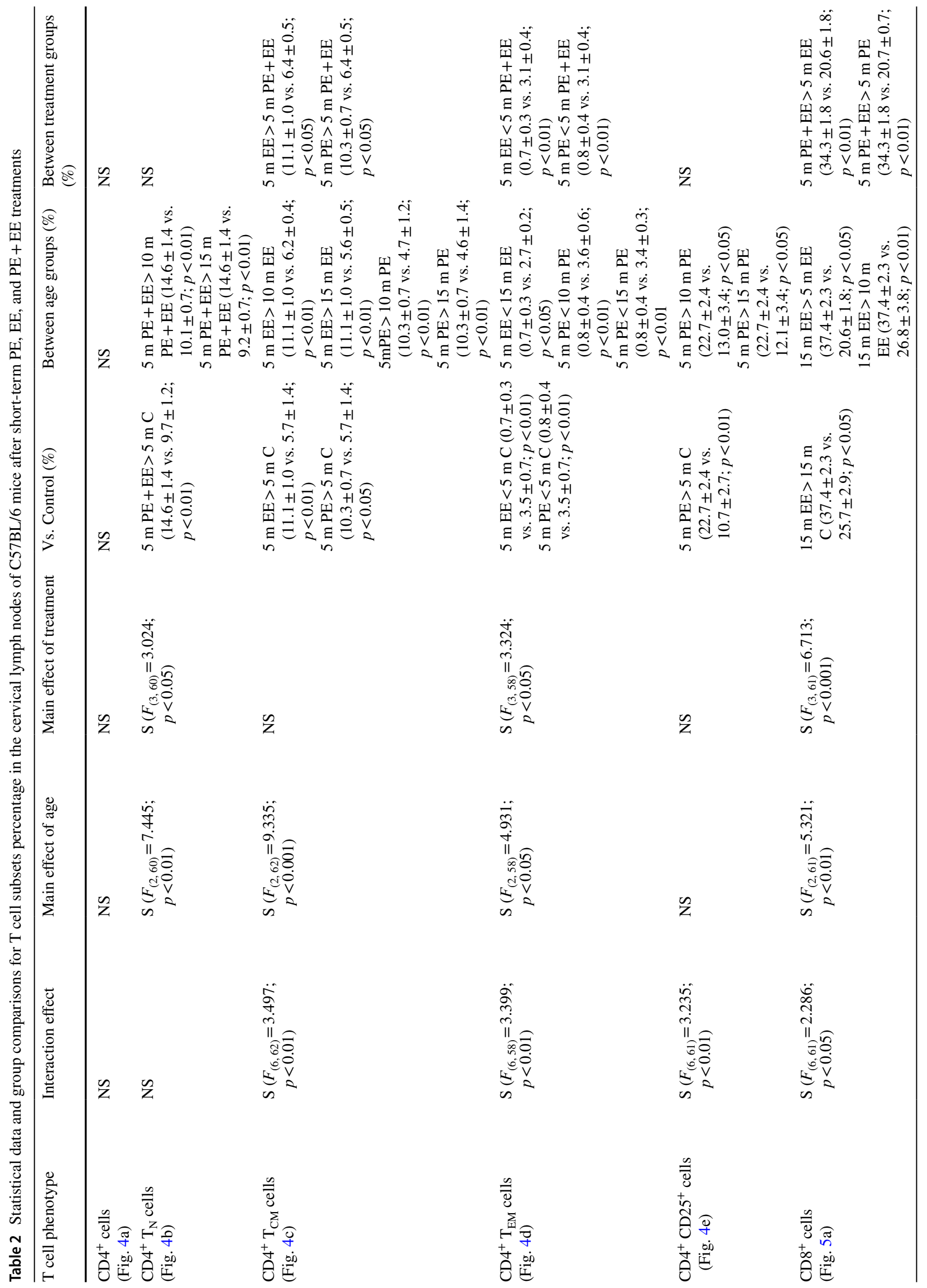


Cellular and Molecular Neurobiology (2021) 41:469-486

477

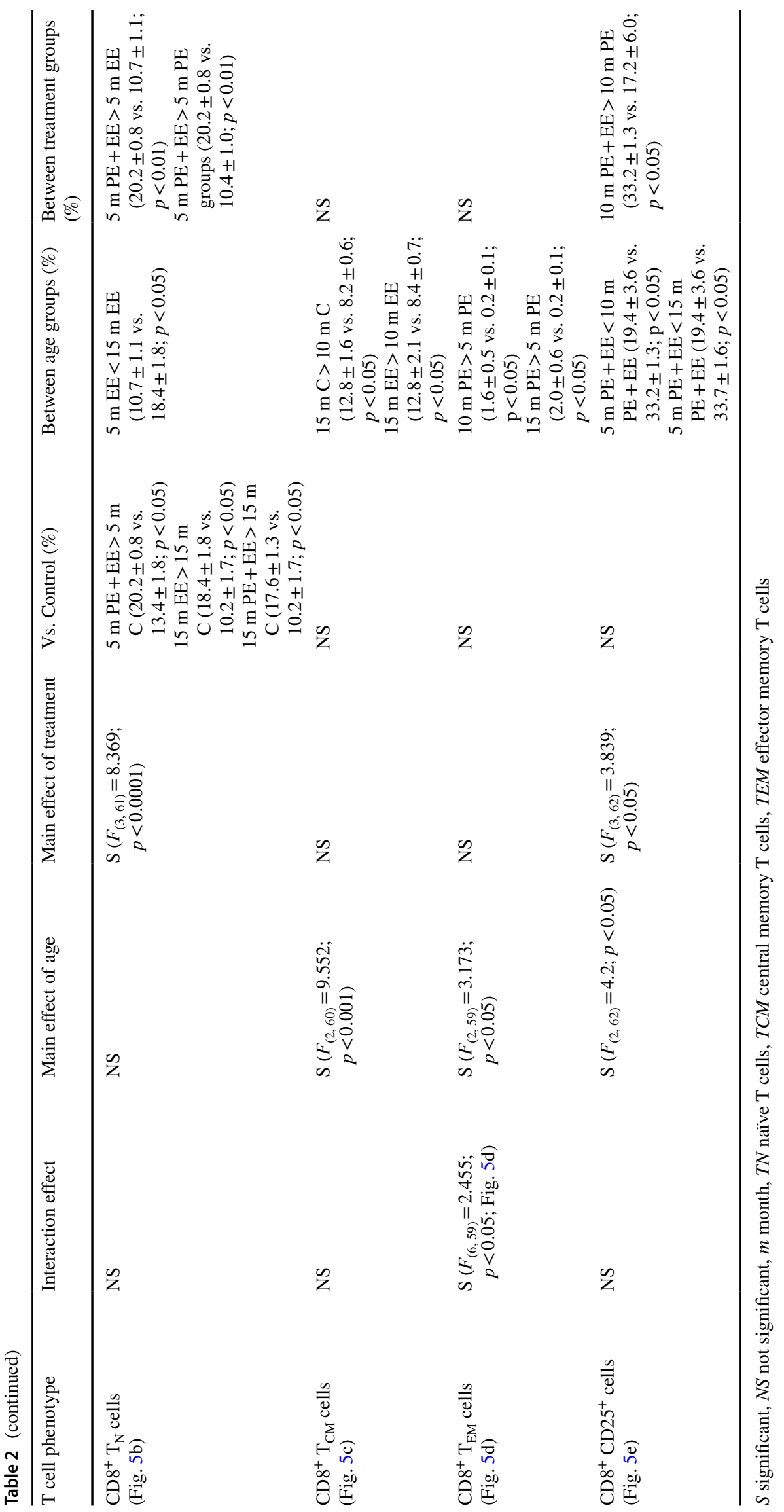

Springer 

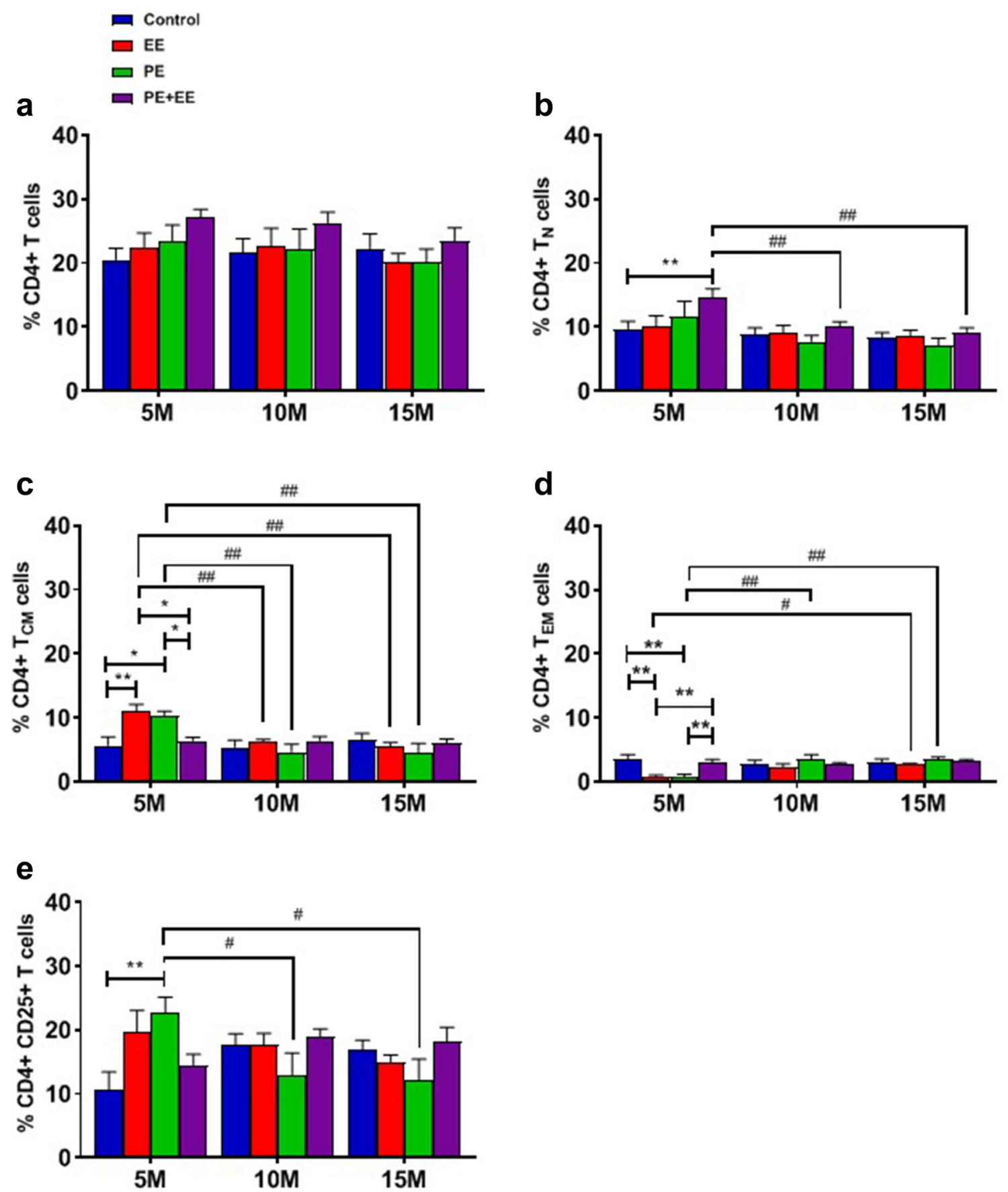

Fig. 4 Proportions of the gated a $\mathrm{CD} 4^{+}, \mathbf{b ~ C D} 4^{+}$naïve, $\mathbf{c ~ C D} 4^{+}$central memory, d CD4 $4^{+}$effector memory, and e $\mathrm{CD} 4^{+} \mathrm{CD} 25^{+} \mathrm{T}$ cells from cervical lymph nodes of 5-, 10- and 15-month-old C57BL/6 mice with or without treatment. Two-way ANOVA in GraphPad Prism. All data represented mean \pm SEM, $n=4-8$ per group. * represents a significant difference between a treatment and age-matched

control or between two treatments at one age point. ${ }^{\#}$ represents a significant difference between the matched treatments over two age points. * and ${ }^{\#} p<0.05$, ** and ${ }^{\# \#} p<0.01$. $M$ month, EE environmental enrichment, $P E$ physical exercise, $N$ naïve, $C M$ central memory, $E M$ effector memory

Fig. 5c) and $\mathrm{T}_{\mathrm{EM}}$ (Table 2; Fig. 5d) cells, and significant main effect of treatment for $\mathrm{CD}^{+} \mathrm{T}_{\mathrm{N}}$ cells (Table 2; Fig. 5b).

On post hoc analysis, significant differences were observed for $\mathrm{CD}^{+} \mathrm{T}_{\mathrm{N}}$ cells between the treatment groups (Table 2; Fig. 5b). The 5-month PE + EE group had a significantly

higher proportion of $\mathrm{CD}^{+} \mathrm{T}_{\mathrm{N}}$ cells compared to 5-month controls, EE, and PE groups. Similarly, the 15-month EE and $\mathrm{PE}+\mathrm{EE}$ groups showed a significantly higher proportion of $\mathrm{CD}^{+} \mathrm{T}_{\mathrm{N}}$ cells than 15-month controls group. Furthermore, the 5-month EE group had a significantly less proportion of 


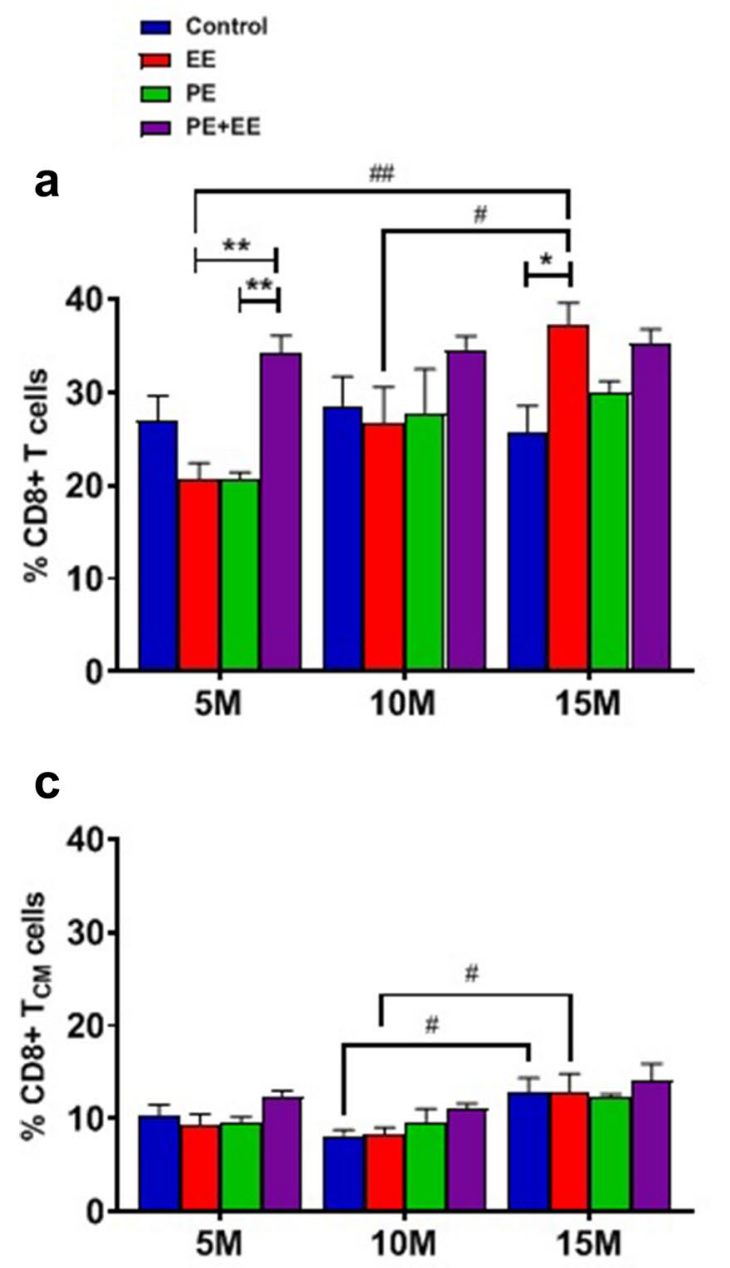

b
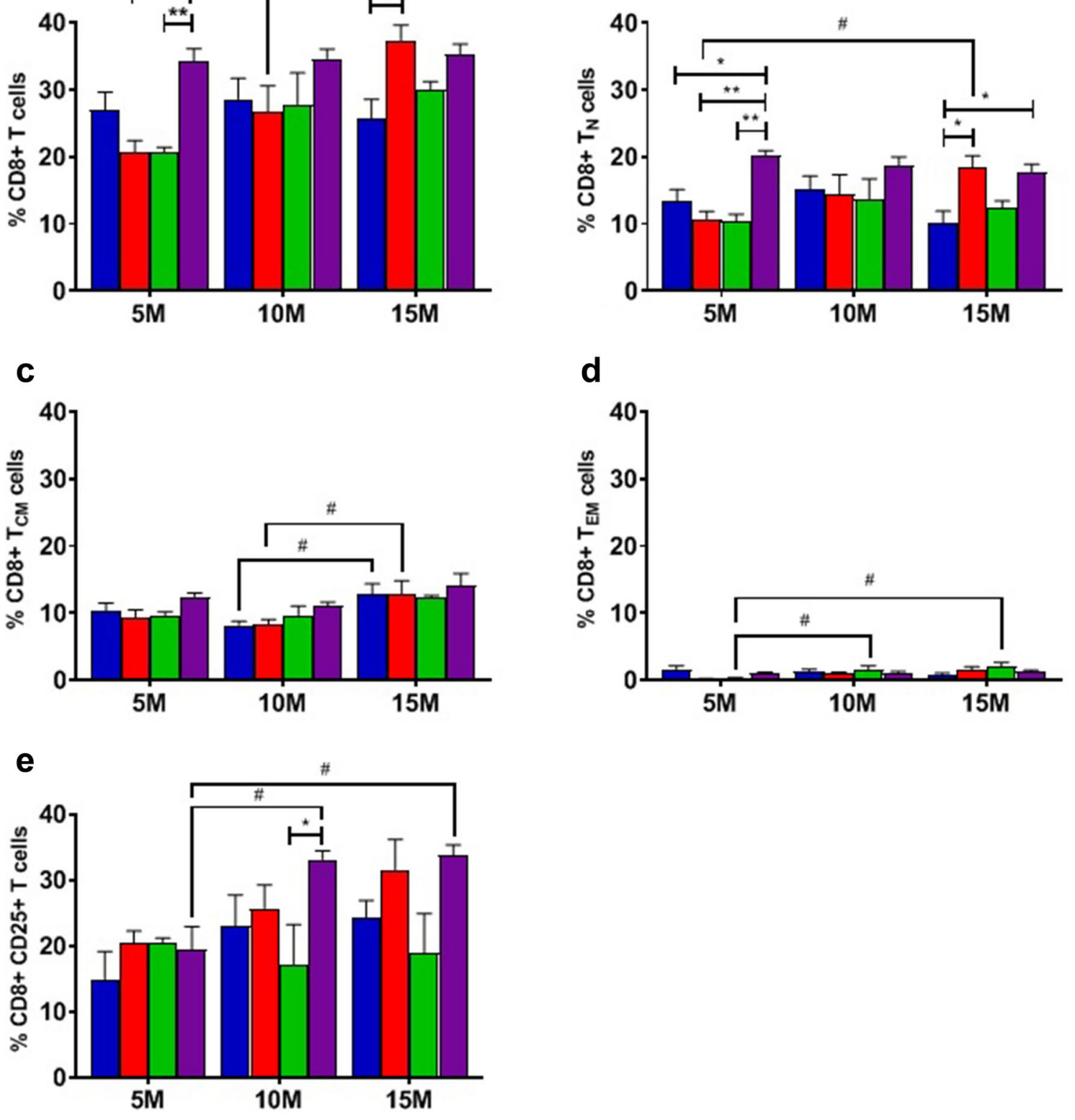

Fig. 5 Proportions of gated a $\mathrm{CD}^{+}, \mathbf{b} \mathrm{CD} 8^{+}$naïve, $\mathbf{c} \mathrm{CD} 8^{+}$central memory, $\mathbf{d ~ C D} 8^{+}$effector memory, and e $\mathrm{CD} 8^{+} \mathrm{CD} 25^{+} \mathrm{T}$ cells from cervical lymph nodes of 5-, 10- and 15-month-old C57BL/6 mice provided with either no treatment (controls), PE, EE, or $\mathrm{PE}+\mathrm{EE}$. Two-way ANOVA in GraphPad Prism. All data represented mean \pm SEM, $n=4-8$ per group. $*$ represents a significant difference

$\mathrm{CD}^{+} \mathrm{T}_{\mathrm{N}}$ cells compared to 15 -month EE group. However, the proportion of $\mathrm{CD} 8^{+} \mathrm{T}_{\mathrm{CM}}$ cells was significantly higher in control and EE groups at 15 months than at 10 months (Table 2; Fig. 5c). In the case of $\mathrm{CD}^{+} \mathrm{T}_{\mathrm{EM}}$ cells, both between a treatment and age-matched control or between two treatments at one age point. " represents a significant difference between the matched treatments over two age points. * and ${ }^{\#} p<0.05$, ** and \#\# $p<0.01$. $M$ month, $E E$ environmental enrichment, $P E$ physical exercise, $N$ naïve, $C M$ central memory, $E M$ effector memory

10- and 15-month PE groups showed a greater proportion of cells than the 5-month PE group (Table 2; Fig. 5d).

We found a non-significant interaction effect but significant main effects of both age and treatment for $\mathrm{CD} 8^{+} \mathrm{CD} 25^{+}$ 
cells (Table 2; Fig. 5e). The post hoc analyses revealed that 5 -month PE + EE group had a significantly lower proportion of $\mathrm{CD} 8^{+} \mathrm{CD} 25^{+} \mathrm{T}$ cells than both 10 - and 15 -month $\mathrm{PE}+\mathrm{EE}$ groups. Additionally, the 10-month PE + EE group showed a significantly higher proportion of $\mathrm{CD} 8^{+} \mathrm{CD} 25^{+} \mathrm{T}$ cells than the 10-month PE group.

\section{Discussion}

In this study, we evaluated the effects of short-term cognitive stimuli and physical activity treatments alone or in combination at three different ages, i.e., 5, 10, and 15 months, on microglia and astrocyte numbers in the dentate gyrus and change in the proportion of peripheral $\mathrm{CD} 4^{+}$and $\mathrm{CD} 8^{+} \mathrm{T}$ cells, their subsets $\left(\mathrm{T}_{\mathrm{N}}, \mathrm{T}_{\mathrm{CM}}, \mathrm{T}_{\mathrm{EM}}\right)$, and $\mathrm{CD} 25^{+} \mathrm{T}$ cells. We observed that while all three treatments reversed the agingrelated decrease in the number of immunopositive microglial cells at middle age, none of them showed any effects on the number of immunopositive astroglial cells at all ages. Additionally, all three treatments were found to modulate the proportion of peripheral $\mathrm{T}$ cell subsets during normal aging, especially at early and late-middle age.

\section{Only Short-Term EE Enhanced Microglial Number at Middle Age, Reversing the Effects of Aging. None of the Treatments Affected Astroglia Number}

We observed a significant increase in the number of immunopositive IBA $1^{+}$microglia after short-term EE at both 5 and 10 months and after short-term PE and PE +EE at 10 months. None of the treatments significantly differed from controls at 15 months. We noticed that the significant increase observed after EE, PE, and PE+EE at 10 months could, in turn, be the result of unusual reduction in the number of IBA $1+$ microglia in 10-month-old control mice. Indeed, 10-month controls also showed a significantly lower number of $\mathrm{IBA} 1^{+}$microglial cells than 5- and 15-month controls. These results are, however, in line with previously published findings where short-term EE significantly increased microglia antigen $\left(\mathrm{IBA}^{+}\right)$expression within the dentate gyrus of adult male Sprague-Dawley rats (Williamson et al. 2012). In addition, we observed that short-term PE+EE mice had significantly more IBA $1^{+}$microglial cells in the dentate gyrus at 15 months compared to 5- and 10-month PE + EE mice.

It must, however, be noted that the phenotype of microglia determines the functional state of microglia. Quiescent microglia within the CNS lack phenotypical markers required for antigen presentation but assist in neuronal migration and repair, recycling of neurotransmitters, regulating ion balance and buffering $\mathrm{pH}$, and maintaining neuronal homeostasis (Singhal and Baune 2017). When activated in the presence of pathogens or stress proteins, microglia quickly proliferate and express major histocompatibility complex (MHC) class I and II proteins, receptors for various cytokines, toll-like receptors, Nod-like receptors, and antigens for $\mathrm{T}$ cell subsets essential to mounting an innate immune response (reactive microglia). The number of reactive microglia increases in areas of neurodegeneration in aging rodents (Singhal and Baune 2017), which has, in turn, been associated with aging-related cognitive and memory impairment (Rozovsky et al. 1998; Sugaya et al. 1996), depression (Norden and Godbout 2013), and neurodegenerative diseases such as AD (Mrak and Griffin 2005). The immunohistochemical stain that we used stained both quiescent and reactive microglia equally; hence, differentiating the two types of microglia was not possible. Also, we investigated mice that aged from early to late-middle age, and not old age, in a relatively stress-free environment, thereby reducing the likelihood of pathogen- and damage-associated molecular patterns (PAMPs and DAMPs) accelerating the microglia-related process. As such, an increase in microglial number during our work is indicative of the effects of normal aging with other external confounders significantly filtered out, and could primarily be due to an increase in the number of quiescent and not reactive microglia. Future research investigating the change in the proportion of two phenotypes after the three treatments is required. This is important especially when the available evidence suggests that altered microglial phenotype modulates affective-like and cognitive behaviors in young and adult rodents (Biscaro et al. 2012; Li et al. 2014; Moraes et al. 2015; Wang et al. 2018). Nonetheless, the depletion in microglial number has also been shown to protect mice for neuroinflammation-associated learning and memory impairment in postoperative young mice (Feng et al. 2017). Likewise, elimination of microglia has shown to improve cognition in six-month-old C56BL/6 mice following cranial irradiation (Acharya et al. 2016). These evidences suggest that change is microglial number may also result in change in behavior.

The overexpression of microglia can result in a significant increase in the production and expression of proinflammatory cytokines (e.g., TNF- $\alpha$, IL- $1 \beta$ ) and neurotoxic substances (e.g., reactive oxygen species, nitric oxide) (Singhal and Baune 2017), subsequently leading to cognitive dysfunction and psychiatric illnesses, such as depression (Patel 2013) and AD (Mrak 2012). However, the increase in the number of microglia may not corroborate fully with the change in microglial functions in the absence of an analysis of microglial activation state. Moreover, we observed no significant change in the microglia number at 15 months after PE and EE. Interestingly, the combination of PE and EE also showed no effects on the increase in microglia number when compared with controls at all three age points. The beneficial effects of the short-term EE on locomotor activity, anxiety-like behavior, and spatial memory at late-middle age that we have reported recently (Singhal et al. 2019) could possibly be due to an 
increase in the number of quiescent microglia. These results, however, do not explain the reported spatial learning impairment and depressive-like behavior at an early age after shortterm PE. Yet, these results are interesting given the microglia are considered the primary immune effector cells in the brain and hence any change in microglial number could be associated with microglial dysfunctioning.

None of the short-term treatments differed significantly from controls for $\mathrm{GFAP}^{+}$astroglial cells at any of the ages. However, 15-month PE mice showed significantly lower expression of $\mathrm{GFAP}^{+}$astroglial cells than 5-month PE mice. It has been reported that during normal aging of the brain, astrocytes reduce in number but their phenotype changes to those of reactive astrocytes, which are the hallmarks of neuroinflammatory disorders (Clarke et al. 2018). These astrocytes affect several neural functions, such as neurotransmission, synaptic plasticity, and neurogenesis, dysregulation of which, in turn, has been associated with the development of psychiatric symptoms (Clarke et al. 2018). Indeed, the association between microglia and astrocytes during old age results in impairment of several vital neuroprotective functions, in particular, the formation and maturation of synapses, neuroinflammation, and neurodegeneration (Dilger and Johnson 2008; Moranis et al. 2012; Wang et al. 2011). As such, we hypothesized a decrease in the number of immunoreactive astrocytes within the dentate gyrus during normal aging. Our results suggest that normal aging until late-middle age has no significant effects on the number of $\mathrm{GFAP}^{+}$astroglial cells in the dentate gyrus. Similarly, no effects of short-term PE, EE, and PE + EE compared to controls were observed on $\mathrm{GFAP}^{+}$astroglial number in the dentate gyrus. Furthermore, although the GFAP ${ }^{+}$astroglial cell number reduced in all 15-month treatment groups when compared to 5-month treatment cohorts, the reduction was significant only in case of short-term PE mice, thereby suggesting that the short-term PE might influence astrocyterelated processes during old age more than short-term EE. Perhaps, the longer duration of PE, EE, and PE + EE treatments may be required to observe a significant change in the $\mathrm{GFAP}^{+}$astroglial cell number in the dentate gyrus.

Together, the results for microglia and astrocytes suggest that any short-term change in behavior or memory may not be accompanied by a concurrent change in glial cell expression and other immune and non-immune factors may be responsible for the reported functional changes (Singhal et al. 2019).

\section{Short-Term PE and EE Did Not Affect the Cervical Lymph Nodes CD4 ${ }^{+} \mathrm{T}$ Cell Subsets Until Late-Middle Age. Only Short-Term PE + EE Enhanced CD4 ${ }^{+} T_{N}$ Cell Proportion at an Early Age}

Ours is the first study to investigate the change in the proportion of $\mathrm{T}$ cell subsets in the cervical lymph nodes in response to short-term EE. The CSF drains to the cervical lymph nodes through the cribroid plate and nasal mucosa, and hence, the analysis of $\mathrm{T}$ cells from the cervical lymph nodes provides a good measure of the $\mathrm{T}$ cell-mediated immunity in the brain (Engelhardt et al. 2016; Goldmann et al. 2006). There were no significant differences found in the overall proportion of $\mathrm{CD}^{+} \mathrm{T}$ cells after short-term treatments at all ages suggesting no effects of the short-term physical exercise or enrichment on helper $\mathrm{T}$ cells. These findings are similar to a male CS mouse study whereby no effect of EE when compared with controls was found on the proportion of $\mathrm{CD} 4+\mathrm{T}$ cells (Marashi et al. 2003). However, this is in contrast to a significant reduction in peripheral blood CD4 + helper T cell proportion in comparison with controls in rats which underwent short-term (4 weeks) PE using a swimming protocol (Kaufman et al. 1994). Similarly, in another rodent study, the combination of PE $+\mathrm{EE}$ was seen to affect $\mathrm{T}$ helper cells. In this case, the reduction in $\mathrm{CD} 4+\mathrm{T}$ helper cell proportions as found in adolescent rat offspring in response to gestational stress was reversed with a short-term $\mathrm{PE}+\mathrm{EE}$ intervention (Laviola et al. 2004). However, moderate endurance training on a treadmill has shown to increase the percentage of $\mathrm{CD} 4+\mathrm{T}$ cells in the Thymus of adult rats, suggesting that the different type of exercise may elicit differnet effects on $\mathrm{T}$ cell subsets in different immune locations (Ferry et al. 1992). It is important to note that differences in genotypes and species across studies mentioned could also contribute to differences in reported findings of peripheral lymphocyte phenotypes.

Further subset analyses of the proportion of $\mathrm{CD} 4^{+} \mathrm{T}$ cells were carried out. The estimation of the $\mathrm{T}$ cell subsets is important in measuring the cell-mediated immune response (Golubovskaya and Wu 2016; Lanzavecchia and Sallusto 2000; Sallusto et al. 1999; Seder and Ahmed 2003). We observed a significantly higher proportion of $\mathrm{T}_{\mathrm{N}}$ cells in the 5-month PE + EE mice compared to 5-month controls and $\mathrm{PE}+\mathrm{EE}$ mice at 10 and 15 months. Moreover, the proportion of $\mathrm{T}_{\mathrm{CM}}$ cells was significantly higher in 5-month $\mathrm{EE}$ and $\mathrm{PE}$ mice when compared to 5-month control mice, and 10- and 15-month mice that received the same treatments. Interestingly, the proportions of $\mathrm{T}_{\mathrm{EM}}$ in 5-month $\mathrm{PE}$ and $\mathrm{EE}$ groups were significantly lower than the same age controls as well as older mice receiving the same treatments. Overall, this suggests that while the combination of short-term $\mathrm{PE}+\mathrm{EE}$ increased the proportion of $\mathrm{CD} 4^{+} \mathrm{T}_{\mathrm{N}}$ cells, $\mathrm{PE}$ or $\mathrm{EE}$ alone did not. On the other hand, short-term PE and EE in isolation not only induced an increase in the proportion of $\mathrm{CD}^{+}$ $\mathrm{T}_{\mathrm{CM}}$ cells but also reduced the proportion $\mathrm{CD} 4^{+} \mathrm{T}_{\mathrm{EM}}$ cells at an early age.

Naïve $\mathrm{T}$ cells become activated, proliferate, differentiate into memory and effector cells, and show upregulation of surface marker $\mathrm{CD} 25^{+}$on encountering a cognate antigen. Studies investigating $\mathrm{T}$ cell receptor responses indicate 
$\mathrm{CD} 4{ }^{+} \mathrm{T}_{\mathrm{N}}$ cells proliferate and convert into memory cells at a lower rate after an initial lag period upon antigen stimulation, in comparison to $\mathrm{CD}^{+} \mathrm{T}_{\mathrm{N}}$ cells (Foulds et al. 2002; Jelley-Gibbs et al. 2000). Similarly, the effects of aging and subsequently of PE on $\mathrm{T}$ cell subsets in Spleen and Thymus have been demonstrated by another study (Woods et al. 2003). The authors reported significantly higher percentage of splenic memory cells and a lower percentage of näive cells in both the $\mathrm{CD}^{+}$and $\mathrm{CD} 8^{+} \mathrm{T}$ cell subsets in 18-month-old BALB/c mice, which was reversed by moderate exercise training of 4 months on a treadmill. No effects of PE was observed on the T cell subsets in Thymus. In contrast, in our study, exposure to either physical or environmental enrichment appears to induce an earlier expansion of $\mathrm{CD} 4+\mathrm{T}_{\mathrm{N}}$ to $\mathrm{CD} 4^{+} \mathrm{T}_{\mathrm{CM}}$ cells in the cervical lymph nodes; however, it must be noted that mice during our study aged only until middle age. Also, the lower proportions of CD4 $+\mathrm{T}_{\mathrm{EM}}$ cells in 5-month PE and EE can be explained by the fact that mice during our experiments were raised in a relatively stress-free environment also devoid of PAMPs. However, aging can also result in the production of DAMPs, which can act as cognate antigens. This might explain the higher proportions of CD4 $+\mathrm{T}_{\mathrm{EM}}$ cells at 10 and 15 months.

The controlled environment could also be the reason for no differences noted in the proportion of $\mathrm{CD} 4{ }^{+} \mathrm{CD} 25^{+}$ cells except for 5-month $\mathrm{PE}$ group showing a significantly higher proportion of $\mathrm{CD} 4^{+} \mathrm{CD} 25^{+}$cells than the 5-month controls and the older mice receiving the same treatment. $\mathrm{CD} 25^{+}$is the alpha chain of the IL-2 receptor and is upregulated following $\mathrm{T}$ cell receptor ligation acquiring high affinity and making cells sensitive for IL-2, also acting as early $\mathrm{T}$ cell activation marker. IL- 2 controls the differentiation and homeostasis of $\mathrm{T}$ cells, thereby regulating cell-mediated immune response. $\mathrm{CD} 4^{+} \mathrm{CD} 25^{+}$cells may be associated with the 'activation,' 'priming,' or 'memory' state of $\mathrm{CD}^{+}$cells (Sakaguchi 2000). Also, since CD4 ${ }^{+}$ $\mathrm{CD} 25^{+}$cells have been reported to suppress proliferation of effector T cells (Sakaguchi et al. 2008; Wing and Sakaguchi 2008), this suggests that short-term PE might help to develop immunological self-tolerance at an early age.

\section{Short-Term EE and PE + EE Increase the Proportion of Peripheral $\mathrm{CDB}^{+} \mathrm{T}_{\mathrm{N}}$ Cells in Young and Late-Middle Age Mice, Respectively. Only PE + EE Increases the Proportion of Early-Activated CD8 ${ }^{+}$T Cells Across All Ages}

We observed that the proportion of peripheral $\mathrm{CD} 8^{+} \mathrm{T}$ cells at the late-middle age increased significantly after short-term EE. However, no change in the proportion of $\mathrm{CD} 8^{+} \mathrm{T}$ cells was noted after both short-term PE and PE $+\mathrm{EE}$ at all ages. This was contrary to the hypothesis that short-term PE will improve neuroimmune functions during normal aging by reducing the proportion of $\mathrm{CD} 8^{+} \mathrm{T}$ cells in $\mathrm{C} 57 \mathrm{BL} / 6$ mice in a controlled environment, as has been reported in the spleens of rodents trained in PE using a swimming protocol over 4 weeks (Kaufman et al. 1994). Similarly, the reduced anxiety-like behavior and improvement in spatial memory at middle and late-middle age, respectively, after short-term EE (Singhal et al. 2019) is not explained by $\mathrm{CD}^{+} \mathrm{T}$ cell results.

$\mathrm{CD} 8+\mathrm{T}_{\mathrm{N}}$ cells require significantly less time of antigen exposure for activation than $\mathrm{CD} 4+\mathrm{T}_{\mathrm{N}}$ cells. This, in turn, translates into the less time required by the $\mathrm{CD} 8+\mathrm{T}_{\mathrm{N}}$ cells to activate, divide and differentiate, and have a faster rate of division than CD4 $+\mathrm{T}_{\mathrm{N}}$ cells (Seder and Ahmed 2003). Furthermore, CD $4+$ effector $\mathrm{T}$ cells are more susceptible to apoptosis at the end of the effector phase than CD8 + effector $\mathrm{T}$ cells. This provides a better opportunity to $\mathrm{CD} 8+$ effector $\mathrm{T}$ cells to develop into stable long-term resting memory cells than CD4 + effector cells. Also, unlike CD4 + memory cells, both $\mathrm{CD} 8+$ memory cell subsets $\left(\mathrm{T}_{\mathrm{CM}}\right.$ and $\left.\mathrm{T}_{\mathrm{EM}}\right)$ are equally efficient in producing effector functions on restimulation with antigen. These differences makes $\mathrm{CD} 8+\mathrm{T}$ cells more potent than $\mathrm{CD} 4+\mathrm{T}$ cells in dispersing cell-mediated immune functions.

Further subset analyses of the proportion of $\mathrm{CD} 8^{+} \mathrm{T}$ cells revealed an increase in proportion of $\mathrm{CD}^{+} \mathrm{T}_{\mathrm{N}}$ but not $\mathrm{T}_{\mathrm{CM}}$ and $\mathrm{T}_{\mathrm{EM}}$ cells after short-term $\mathrm{EE}$ at late-middle age. However, a human study has shown that aging is associated with a decrease in $\mathrm{CD}^{+} \mathrm{T}_{\mathrm{N}}$ cells in donor cervical lymph nodes (Lazuardi et al. 2005). This suggests that EE improves basal cytotoxic immunity during the late-middle-age reversing the age-related effects. This, possibly also explains the reported improvement in brain functions after short-term EE (Singhal et al. 2019). In contrast, we observed that the combination of short-term PE and EE also increased the proportion of $\mathrm{CD}^{+} \mathrm{T}_{\mathrm{N}}$ cells, but only at an early age and not at middle and late-middle age. These results are interesting and show the influence that the inclusion of a running wheel in EE paradigms can have on cell-mediated immunity. Furthermore, the proportion of $\mathrm{CD}^{+} \mathrm{T}_{\mathrm{CM}}$ cells in the cervical lymph nodes of control mice significantly increased from middle to late-middle age. This can again be explained by the fact that there is an increase in the production of DAMPs during aging, which may act as cognate antigens stimulating the conversion of the peripheral $\mathrm{CD} 8^{+} \mathrm{T}_{\mathrm{N}}$ cells to $\mathrm{CD} 8^{+} \mathrm{T}_{\mathrm{CM}}$ cells. The latter have little or no effector function but mediate reactive memory where they migrate to secondary lymphoid organs, and some of them proliferate and differentiate into effector cells in response to antigenic stimulation, thus helping the body to resolve inflammation (Liao et al. 2011). The proportion of $\mathrm{CD}^{+} \mathrm{T}_{\mathrm{EM}}$ cells in the cervical lymph nodes of 5-month PE mice was significantly lower compared to older PE groups. Since the $\mathrm{CD} 8^{+} \mathrm{T}_{\mathrm{EM}}$ cells are important mediators of protective memory as mentioned before, the 
lower number of $\mathrm{CD}^{+} \mathrm{T}_{\mathrm{EM}}$ cells after PE at 5 months suggests that perhaps the cell-mediated immunity gets compromised after short-term PE at an early age, which may have a role to play in the reported development of depressive-like behavior in young mice (Singhal et al. 2019).

The combination of short-term PE with EE significantly improved the proportion of early-activated $\mathrm{CD} 8^{+} \mathrm{CD} 25^{+}$ $\mathrm{T}$ cell from middle age onwards when compared to early age $\mathrm{PE}+\mathrm{EE}$ mice, suggesting that $\mathrm{PE}+\mathrm{EE}$ might enhance $\mathrm{CD} 8+\mathrm{T}$ cell responsiveness if provided in combination and for long-term (Backer et al. 2018). Further research into investigating the effects of long-term PE, EE, and their combination on aging-associated changes in $\mathrm{T}$ cell subset proportions is required.

\section{Limitations of the Study and Future Directions}

We conducted behavioral testing during the last three weeks before collecting brain samples for IHC and FACS. As such, there is a possibility that other factors, such as social or handling stress (Hardy et al. 1990; Stefanski 2001; Stefanski and Engler 1999) and sensory stimulation (Roberts 1995, 2000), could have modulated glia and $\mathrm{T}$ cell subset numbers. The composition of EE objects, i.e., wood or plastic, soft or hard, may also have a significant impact on the observed results. These variables must be explored in detail in future research investigating the effects of PE and EE on neuroimmune mechanisms. Furthermore, it is the primed phenotype of glial cells that drives neuroinflammation and the subsequent functional changes. This encompasses much more than an increase in the number of immunopositive glial cells in the dentate gyrus. Hence, examining the morphology of glial cells (quiescent and reactive microglia) and levels of other activation markers, for example cytokines, chemokines, C-reactive protein, and protein kinases, is required to develop full understanding of an inflammatory phenotype after the three treatments. T cells from cervical lymph nodes are good representatives of $\mathrm{T}$ cells in the brain. However, comparison between the $\mathrm{T}$ cells obtained from other key regions, such as blood, thymus, and cerebrospinal fluid, is required to develop better understanding. Our immune results, therefore, do not make a full profile of the inflammatory phenotype during normal aging and may not fully explain the reported change in brain functions after the three treatments (Singhal et al. 2019). However, we have provided a foundation towards developing understanding on the role of PE and EE in the modulation of brain glial cells and peripheral $\mathrm{T}$ cells.

\section{Conclusion}

Our study is the first to investigate the change in the number of brain glia cells and T cell subsets within the cervical lymph nodes of immunologically unchallenged mice in response to short-term $\mathrm{PE}, \mathrm{EE}$, and $\mathrm{PE}+\mathrm{EE}$ across the lifespan. Our findings suggest that both short-term PE and EE elicit neuroimmune changes during normal aging. We noted that the effect of short-term EE alone on glial cells is stronger. Furthermore, both short-term PE and EE enhance cytotoxic immune potential by increasing the proportion of $\mathrm{CD}^{+} \mathrm{T}_{\mathrm{N}}$ cells. Similarly, the combination of short-term $\mathrm{PE}$ and $\mathrm{EE}$ led to an increase in the proportion of earlyactivated CD8 $+\mathrm{T}$ cells, suggesting enhanced cytotoxic immunity. We also conclude that the neuroimmune effect of short-term PE and EE is not additive.

Acknowledgements Open Access funding provided by Projekt DEAL. The presented work is supported by the National Health and Medical Research Council Australia (APP 1043771 to BTB). AJH is an NHMRC Principal Research Fellow. Many thanks to the University of Adelaide for giving me the fantastic opportunity of working in one of the world's best facilities alongside world-renowned researchers; the National Health and Medical Research Council (NHMRC) for the financial support of this project without which this work would not have been possible; Ms. Katherine Pilkington and Ms. Rebecca Bassmann for their guidance with Fluorescent Activated Cell Sorting analysis; and Ms. Pacita Wissell and staff at the Laboratory Animal Services, The University of Adelaide, for their assistance with mouse husbandry work.

Author Contributions All authors contributed to the study conception and design. Material preparation, data collection and analysis were performed by GS. JM assisted GS with the mouse husbandry work and collection of data. FC, CT, and JM assisted GS with the molecular analysis. $\mathrm{AH}$ provided technical guidance during the study as and when needed. FC, MCJ, EJJ, and BTB supervised the project. The first draft of the manuscript was written by GS and all authors commented on previous versions of the manuscript. All authors read and approved the final manuscript.

Funding The funders had no role in study design, data collection, analysis, decision to publish, or preparation of the manuscript.

\section{Compliance with Ethical Standards}

Ethical Approval All applicable international, national, and/or institutional guidelines for the care and use of animals were followed. Ethical approval for performing experiments on C57BL/6 mice was received from the University of Adelaide Animal Ethics Committee (M216-12), and all guidelines as prescribed for handling experimental animals were adhered to during the study.

Open Access This article is licensed under a Creative Commons Attribution 4.0 International License, which permits use, sharing, adaptation, distribution and reproduction in any medium or format, as long as you give appropriate credit to the original author(s) and the source, provide a link to the Creative Commons licence, and indicate if changes were made. The images or other third party material in this article are included in the article's Creative Commons licence, unless indicated 
otherwise in a credit line to the material. If material is not included in the article's Creative Commons licence and your intended use is not permitted by statutory regulation or exceeds the permitted use, you will need to obtain permission directly from the copyright holder. To view a copy of this licence, visit http://creativecommons.org/licenses/by/4.0/.

\section{References}

Acharya MM et al (2016) Elimination of microglia improves cognitive function following cranial irradiation. Sci Rep 6:1-11

Ahmadiasl N, Alaei H, Hanninen O (2003) Effect of exercise on learning, memory and levels of epinephrine in rats hippocampus. $\mathbf{J}$ Sports Sci Med 2:106-109

Arranz L, De Castro NM, Baeza I, Maté I, Viveros MP, De la Fuente M (2010) Environmental enrichment improves age-related immune system impairment: long-term exposure since adulthood increases life span in mice. Rejuvenation Res 13:415-428

Backer RA, Hombrink P, Helbig C, Amsen D (2018) The fate choice between effector and memory $\mathrm{T}$ cell lineages: asymmetry, signal integration, and feedback to create bistability. In: Advances in immunology, vol 137. Elsevier, pp 43-82

Baumans V (2005) Environmental enrichment for laboratory rodents and rabbits: requirements of rodents, rabbits, and research. ILAR J 46:162-170

Benaroya-Milshtein N et al (2004) Environmental enrichment in mice decreases anxiety, attenuates stress responses and enhances natural killer cell activity. Eur J Neurosci 20:1341-1347

Berardi N, Braschi C, Capsoni S, Cattaneo A, Maffei L (2007) Environmental enrichment delays the onset of memory deficits and reduces neuropathological hallmarks in a mouse model of Alzheimer-like neurodegeneration. J Alzheimer's Dis 11:359-370

Binder E, Droste SK, Ohl F, Reul JM (2004) Regular voluntary exercise reduces anxiety-related behaviour and impulsiveness in mice. Behav Brain Res 155:197-206

Biscaro B, Lindvall O, Tesco G, Ekdahl CT, Nitsch RMJND (2012) Inhibition of microglial activation protects hippocampal neurogenesis and improves cognitive deficits in a transgenic mouse model for Alzheimer's disease. Neurodegener Dis 9:187-198

Chabry $\mathbf{J}$ et al (2015) Enriched environment decreases microglia and brain macrophages inflammatory phenotypes through adiponectin-dependent mechanisms: relevance to depressive-like behavior. Brain Behav Immun 50:275-287

Clarke LE, Liddelow SA, Chakraborty C, Münch AE, Heiman M, Barres BA (2018) Normal aging induces A1-like astrocyte reactivity. Proc Natl Acad Sci 115:E1896-E1905

Conde JR, Streit WJ (2006) Microglia in the aging brain. J Neuropathol Exp Neurol 65:199-203

Dantzer R, O'Connor JC, Freund GG, Johnson RW, Kelley KW (2008) From inflammation to sickness and depression: when the immune system subjugates the brain. Nat Rev Neurosci 9:46

Dilger RN, Johnson RW (2008) Aging, microglial cell priming, and the discordant central inflammatory response to signals from the peripheral immune system. J Leukoc Biol 84:932-939. https://doi. org/10.1189/jlb.0208108

Ehninger D, Kempermann G (2003) Regional effects of wheel running and environmental enrichment on cell genesis and microglia proliferation in the adult murine neocortex. Cereb Cortex 13:845-851

Eikelenboom P, Veerhuis R, Scheper W, Rozemuller A, van Gool WA, Hoozemans J (2006) The significance of neuroinflammation in understanding Alzheimer's disease. J Neural Transm 113:1685

Engelhardt B, Carare RO, Bechmann I, Flügel A, Laman JD, Weller RO (2016) Vascular, glial, and lymphatic immune gateways of the central nervous system. Acta Neuropathol 132:317-338
Engin E, Treit D (2007) The role of hippocampus in anxiety: intracerebral infusion studies. Behav Pharmacol 18:365-374

Faherty CJ, Shepherd KR, Herasimtschuk A, Smeyne RJ (2005) Environmental enrichment in adulthood eliminates neuronal death in experimental Parkinsonism. Mol Brain Res 134:170-179

Falkenberg T, Mohammed AK, Henriksson B, Persson H, Winblad B, Lindefors N (1992) Increased expression of brain-derived neurotrophic factor mRNA in rat hippocampus is associated with improved spatial memory and enriched environment. Neurosci Lett 138:153-156

Feng X, Valdearcos M, Uchida Y, Lutrin D, Maze M, Koliwad SKJJ (2017) Microglia mediate postoperative hippocampal inflammation and cognitive decline in mice. JCI Insight 2:e91229

Ferry A, Rieu P, Laziri F, El Habazi A, Le Page C, Rieu M (1992) Effect of moderate exercise on rat T-cells. Eur J Appl Physiol 65:464-468

Foulds KE, Zenewicz LA, Shedlock DJ, Jiang J, Troy AE, Shen H (2002) Cutting edge: CD4 and CD8 T cells are intrinsically different in their proliferative responses. J Immunol 168:1528-1532

Goldmann J, Kwidzinski E, Brandt C, Mahlo J, Richter D, Bechmann I (2006) T cells traffic from brain to cervical lymph nodes via the cribroid plate and the nasal mucosa. J Leukoc Biol 80:797-801

Golubovskaya V, Wu L (2016) Different subsets of T cells, memory, effector functions, and CAR-T immunotherapy. Cancers 8:36

Gruver A, Hudson L, Sempowski G (2007) Immunosenescence of ageing. J Pathol 211:144-156

Hanisch UK (2002) Microglia as a source and target of cytokines. Glia 40:140-155

Hannan A (2014) Environmental enrichment and brain repair: harnessing the therapeutic effects of cognitive stimulation and physical activity to enhance experience-dependent plasticity. Neuropathol Appl Neurobiol 40:13-25

Hardy C-A, Quay J, Livnat S, Ader R (1990) Altered T-lymphocyte response following aggressive encounters in mice. Physiol Behav $47: 1245-1251$

Jankowsky JL et al (2005) Environmental enrichment mitigates cognitive deficits in a mouse model of Alzheimer's disease. J Neurosci 25:5217-5224

Jelley-Gibbs DM, Lepak NM, Yen M, Swain SL (2000) Two distinct stages in the transition from naive CD4 T cells to effectors, early antigen-dependent and late cytokine-driven expansion and differentiation. J Immunol 165:5017-5026

Kaufman JC, Harris TJ, Higgins J, Maisel AS (1994) Exerciseinduced enhancement of immune function in the rat. Circulation 90:525-532

Kempermann G, Gast D, Gage FH (2002) Neuroplasticity in old age: Sustained fivefold induction of hippocampal neurogenesis by long-term environmental enrichment. Ann Neurol 52:135-143

Kuzumaki N et al (2010) Enhanced IL-1 $\beta$ production in response to the activation of hippocampal glial cells impairs neurogenesis in aged mice. Synapse 64:721-728

Lanzavecchia A, Sallusto F (2000) Dynamics of T lymphocyte responses: intermediates, effectors, and memory cells. Science 290:92-97

Laviola $G$ et al (2004) Beneficial effects of enriched environment on adolescent rats from stressed pregnancies. Eur J Neurosci 20:1655-1664

Lazuardi L, Jenewein B, Wolf AM, Pfister G, Tzankov A, GrubeckLoebenstein B (2005) Age-related loss of naive T cells and dysregulation of T-cell/B-cell interactions in human lymph nodes. Immunology 114:37-43

Leggio MG, Mandolesi L, Federico F, Spirito F, Ricci B, Gelfo F, Petrosini L (2005) Environmental enrichment promotes improved spatial abilities and enhanced dendritic growth in the rat. Behav Brain Res 163:78-90 
Li Z, Ma L, Kulesskaya N, Võikar V, Tian LJB (2014) Microglia are polarized to $\mathrm{M} 1$ type in high-anxiety inbred mice in response to lipopolysaccharide challenge. Brain Behav Immun 38:237-248

Liao W, Lin J-X, Leonard WJ (2011) IL-2 family cytokines: new insights into the complex roles of IL-2 as a broad regulator of T helper cell differentiation. Curr Opin Immunol 23:598-604. https ://doi.org/10.1016/j.coi.2011.08.003

Linton PJ, Dorshkind K (2004) Age-related changes in lymphocyte development and function. Nat Immunol 5:133

Maier SF, Watkins LR (1998) Cytokines for psychologists: implications of bidirectional immune-to-brain communication for understanding behavior, mood, and cognition. Psychol Rev 105:83

Marashi V, Barnekow A, Ossendorf E, Sachser N (2003) Effects of different forms of environmental enrichment on behavioral, endocrinological, and immunological parameters in male mice. Horm Behav 43:281-292

Marashi V, Barnekow A, Sachser N (2004) Effects of environmental enrichment on males of a docile inbred strain of mice. Physiol Behav 82:765-776

Moncek F, Duncko R, Johansson B, Jezova D (2004) Effect of environmental enrichment on stress related systems in rats. J Neuroendocrinol 16:423-431

Montecino-Rodriguez E, Berent-Maoz B, Dorshkind K (2013) Causes, consequences, and reversal of immune system aging. J Clin Investig 123:958-965

Moraes CA, Santos G, D’Avila JC, Lima FRS, Benjamim CF, Bozza FA, Gomes FCAJM (2015) Activated microglia-induced deficits in excitatory synapses through IL-1 $\beta$ : implications for cognitive impairment in sepsis. Mol Neurobiol 52:653-663

Moranis A et al (2012) Long term adequate n-3 polyunsaturated fatty acid diet protects from depressive-like behavior but not from working memory disruption and brain cytokine expression in aged mice. Brain Behav Immun 26:721-731

Morley-Fletcher S, Rea M, Maccari S, Laviola G (2003) Environmental enrichment during adolescence reverses the effects of prenatal stress on play behaviour and HPA axis reactivity in rats. Eur J Neurosci 18:3367-3374

Moro-García MA, Alonso-Arias R, López-Larrea C (2013) When aging reaches $\mathrm{CD} 4+\mathrm{T}$-cells: phenotypic and functional changes. Front Immunol 4:107

Mrak RE (2012) Microglia in Alzheimer brain: a neuropathological perspective. Int J Alzheimer's Dis 2012:165021

Mrak RE, Griffin WST (2005) Glia and their cytokines in progression of neurodegeneration. Neurobiol Aging 26:349-354

Nichol K, Deeny SP, Seif J, Camaclang K, Cotman CW (2009) Exercise improves cognition and hippocampal plasticity in APOE $\varepsilon 4$ mice. Alzheimer's Dement 5:287-294

Norden DM, Godbout JP (2013) Review: microglia of the aged brain: primed to be activated and resistant to regulation. Neuropathol Appl Neurobiol 39:19-34. https://doi.org/10.111 1/j.1365-2990.2012.01306.x

Parasuraman S, Raveendran R, Kesavan R (2010) Blood sample collection in small laboratory animals. J Pharmacol Pharmacother 1:87

Patel A (2013) Review: the role of inflammation in depression. Psychiatr Danub 25:S216-223

Roberts JE (1995) Visible light induced changes in the immune response through an eye-brain mechanism (photoneuroimmunology). J Photochem Photobiol B 29:3-15

Roberts JE (2000) Light and immunomodulation. Ann N Y Acad Sci 917:435-445

Ron-Harel N, Cardon M, Schwartz M (2011) Brain homeostasis is maintained by "danger" signals stimulating a supportive immune response within the brain's borders. Brain Behav Immun 25:1036-1043
Rothwell NJ, Luheshi G, Toulmond S (1996) Cytokines and their receptors in the central nervous system: physiology, pharmacology, and pathology. Pharmacol Ther 69:85-95

Rozovsky I, Finch C, Morgan T (1998) Age-related activation of microglia and astrocytes: in vitro studies show persistent phenotypes of aging, increased proliferation, and resistance to downregulation. Neurobiol Aging 19:97-103

Sakaguchi S (2000) Regulatory T cells: key controllers of immunologic self-tolerance. Cell 101:455-458

Sakaguchi S, Yamaguchi T, Nomura T, Ono M (2008) Regulatory T cells and immune tolerance. Cell 133:775-787

Sallusto F, Lenig D, Förster R, Lipp M, Lanzavecchia A (1999) Two subsets of memory $\mathrm{T}$ lymphocytes with distinct homing potentials and effector functions. Nature 401:708

Sampedro-Piquero P, Zancada-Menendez C, Begega A, Rubio S, Arias J (2013) Effects of environmental enrichment on anxiety responses, spatial memory and cytochrome c oxidase activity in adult rats. Brain Res Bull 98:1-9

Schacter DL, Savage CR, Alpert NM, Rauch SL, Albert MS (1996) The role of hippocampus and frontal cortex in age-related memory changes: a PET study. NeuroReport 7:1165-1169

Schipper HM (1996) Astrocytes, brain aging, and neurodegeneration. Neurobiol Aging 17:467-480

Scoville WB, Milner B (1957) Loss of recent memory after bilateral hippocampal lesions. J Neurol Neurosurg Psychiatry 20:11

Seder RA, Ahmed R (2003) Similarities and differences in CD4+ and CD8+ effector and memory $\mathrm{T}$ cell generation. Nat Immunol 4:835

Segovia G, Yagüe AG, García-Verdugo JM, Mora F (2006) Environmental enrichment promotes neurogenesis and changes the extracellular concentrations of glutamate and GABA in the hippocampus of aged rats. Brain Res Bull 70:8-14

Singhal G, Baune BT (2017) Microglia: an interface between the loss of neuroplasticity and depression. Front Cell Neurosci 11:270

Singhal G, Jaehne EJ, Corrigan F, Baune BT (2014) Cellular and molecular mechanisms of immunomodulation in the brain through environmental enrichment. Front Cell Neurosci 8:97

Singhal G et al (2019) Short-term environmental enrichment, and not physical exercise, alleviate cognitive decline and anxiety from middle age onwards without affecting hippocampal gene expression. Cognit Affect Behav Neurosci 19:1143

Soffié M, Hahn K, Terao E, Eclancher F (1999) Behavioural and glial changes in old rats following environmental enrichment. Behav Brain Res 101:37-49

Song HK, Hwang DY (2017) Use of C57BL/6N mice on the variety of immunological researches. Lab Anim Res 33:119-123

Spires TL, Grote HE, Varshney NK, Cordery PM, van Dellen A, Blakemore C, Hannan AJ (2004) Environmental enrichment rescues protein deficits in a mouse model of Huntington's disease, indicating a possible disease mechanism. J Neurosci 24:2270-2276

Stefanski V (2001) Social stress in laboratory rats: behavior, immune function, and tumor metastasis. Physiol Behav 73:385-391

Stefanski V, Engler H (1999) Social stress, dominance and blood cellular immunity. J Neuroimmunol 94:144-152

Sugaya K et al (1996) Molecular indices of neuronal and glial plasticity in the hippocampal formation in a rodent model of age-induced spatial learning impairment. J Neurosci 16:3427-3443

Thoman M, Weigle W (1982) Cell-mediated immunity in aged mice: an underlying lesion in IL 2 synthesis. J Immunol 128:2358-2361

Van der Borght K, Havekes R, Bos T, Eggen BJ, Van der Zee EA (2007) Exercise improves memory acquisition and retrieval in the Y-maze task: relationship with hippocampal neurogenesis. Behav Neurosci 121:324 
Van Praag H, Shubert T, Zhao C, Gage FH (2005) Exercise enhances learning and hippocampal neurogenesis in aged mice. J Neurosci $25: 8680-8685$

Wang $\mathrm{M}$ et al (2011) Neuronal basis of age-related working memory decline. Nature 476:210-213. https://doi.org/10.1038/nature10243

Wang Y-L et al (2018) Microglial activation mediates chronic mild stress-induced depressive-and anxiety-like behavior in adult rats. J Neuroinflammation 15:21

Williamson LL, Chao A, Bilbo SD (2012) Environmental enrichment alters glial antigen expression and neuroimmune function in the adult rat hippocampus. Brain Behav Immun 26:500-510
Wing K, Sakaguchi S (2008) 16-regulatory T cells. In: Rich RR, Fleisher TA, Shearer WT, Schroeder HW, Frew AJ, Weyand CM (eds) Clinical immunology, 3rd edn. Mosby, Edinburgh, pp 249-258

Woods J, Ceddia M, Zack M, Lowder T, Lu QJB (2003) Exercise training increases the näive to memory $\mathrm{T}$ cell ratio in old mice. Brain Behav Immun 17:384-392

Publisher's Note Springer Nature remains neutral with regard to jurisdictional claims in published maps and institutional affiliations.

\section{Affiliations}

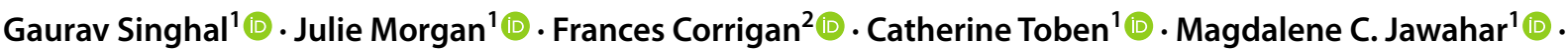

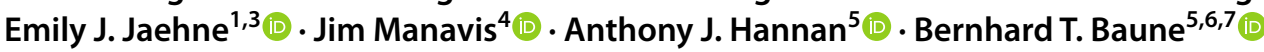

Gaurav Singhal

Gaurav.Singhal@adelaide.edu.au

Julie Morgan

Julie.Morgan@adelaide.edu.au

Frances Corrigan

Frances.Corrigan@unisa.edu.au

Catherine Toben

Catherine.Toben@adelaide.edu.au

Magdalene C. Jawahar

Catharine.Jawahar@adelaide.edu.au

Emily J. Jaehne

E.Jaehne@latrobe.edu.au

Jim Manavis

Jim.Manavis@adelaide.edu.au

Anthony J. Hannan

Anthony.Hannan@florey.edu.au
Psychiatric Neuroscience Lab, Discipline of Psychiatry, The University of Adelaide, Adelaide, Australia

2 Division of Health Sciences, The University of South Australia, Adelaide, Australia

3 School of Psychology and Public Health, La Trobe University, Bundoora, Melbourne, Australia

4 Centre for Neurological Diseases, School of Medicine, Faculty of Health, The University of Adelaide, Adelaide, Australia

5 Florey Institute of Neuroscience and Mental Health, The University of Melbourne, Melbourne, Australia

6 Department of Psychiatry, Melbourne Medical School, The University of Melbourne, Melbourne, Australia

7 Department of Psychiatry, The University of Münster, Münster, Germany 